\title{
MAP SHOWING OUTCROPS OF GRANITIC ROCKS, BASIN AND RANGE PROVINCE, NEVADA
}

Compiled by $K$. A. Sargent and Kurt Roggensack

\section{INTRODUCTION}

This map report is one of a series of geologic and hydrologic maps covering all or parts of States within the Basin and Range province of the western United states. The map reports contain information on subjects that characterize the geohydrology of the province, including the ground-water hydrology, ground-water quality, surface distribution of selected rock types, tectonic conditions, areal geophysics, Pleistocene lakes and marshes, and mineral and energy resources. This work is a part of the U.S. Geological survey's program for geologic and hydrologic evaluation of the Basin and Range province to identify potentially suitable regions for further study relative to isolation of high-level nuclear waste (Bedinger, Sargent, and Reed, 1984).

Data for this report were taken largely from spengler and others (1979), supplemented by data from individual geologic maps and reports, following the project guidelines as defined in Sargent and Bedinger (1984). As used in this report, granitic rocks include granodiorite, quartz monzonite, and granite, and locally associated mafic rocks such as diorite and gabbro. In the Snake Range and Ruby Mountains, Stewart (1980) has recognized large areas as metamorphic core complexes, and in these complexes some plutonic masses may not extend to great depth because of lateral displacement along low-angle faults subsequent to intrusion.

The Description of Map Units includes the sources of data, the geologic, and if available, the radiometric age, lithologic character, type of intrusive body and relation to rock units, where known, for the granitic rocks within outlined and numbered areas in each county of the study area. The radiometric ages of the rock units are only those which are available and do not necessarily represent the entire age range of the geologic units. 


\begin{tabular}{|c|c|c|c|c|}
\hline $\begin{array}{l}\text { County- } \\
\text { area } \\
\text { rumber }\end{array}$ & $\begin{array}{c}\text { Map } \\
\text { symbol }\end{array}$ & $\begin{array}{l}\text { Geologic and } \\
\text { radiometric age } \\
\text { in millions of } \\
\text { years (m.y.) }\end{array}$ & $\begin{array}{c}\text { Lithology } \\
\text { and } \\
\text { comments }\end{array}$ & $\begin{array}{c}\text { References } \\
\text { for } \\
\text { county area }\end{array}$ \\
\hline
\end{tabular}

\begin{tabular}{|c|c|c|c|c|}
\hline $\mathrm{CH}-1$ & $\mathrm{Kg}$ & $\begin{array}{l}\text { Late Cretaceous } \\
75.9 \pm 1.5\end{array}$ & $\begin{array}{l}\text { Medium-grained quartz } \\
\text { monzonite and granodiorite(?) } \\
\text { pluton intrudes Lower Jurassic } \\
\text { calcareous siltstone and } 1 \text { ime- } \\
\text { stone. Low-grade metamorphism } \\
\text { pervasive around the body. }\end{array}$ & $\begin{array}{l}\text { Speed and } \\
\text { Armstrong, } 1971 ; \\
\text { Spengler and } \\
\text { others, } 1979 ; \\
\text { Willden and } \\
\text { speed, } 1974\end{array}$ \\
\hline $\mathrm{CH}-2$ & $\mathrm{Tg}$ & $\begin{array}{l}\text { Miocene } \\
\text { to oligocerie } \\
28 \pm 2 \mathrm{~m} \cdot \mathrm{y} .\end{array}$ & $\begin{array}{l}\text { IXL Canyon pluton: } \\
\text { Composite, fine- to coarse- } \\
\text { grained quartz-monzonite } \\
\text { pluton intrudes and meta- } \\
\text { morphoses Tertiary volcanic } \\
\text { rocks and Late Triassic } \\
\text { sedimentary rocks. }\end{array}$ & $\begin{array}{l}\text { Speed and } \\
\text { Armstrong, } 1971 ; \\
\text { Spengler and } \\
\text { others, } 1979 ; \\
\text { Willden and } \\
\text { Speed, } 1974\end{array}$ \\
\hline $\mathrm{CH}-3$ & $\mathrm{Kg}$ & $\begin{array}{l}\text { Cretaceous } \\
103 \pm 2 \\
\mathrm{~m} \cdot \mathrm{y}\end{array}$ & $\begin{array}{l}\text { Granodiorite and quartz } \\
\text { monzonite pluton intrudes } \\
\text { Upper Triassic siltstone and } \\
\text { sandstone. Partly over- } \\
\text { lain by Tertiary volcanics. } \\
\text { Locally bounded by high- } \\
\text { angle faults. }\end{array}$ & $\begin{array}{l}\text { Speed and } \\
\text { Armstrong, } 1971 ; \\
\text { Spengler and } \\
\text { others, } 1979 ; \\
\text { Willden and } \\
\text { Speed, } 1974\end{array}$ \\
\hline $\mathrm{CH}-4$ & $\mathrm{Kg}$ & $\begin{array}{l}\text { Cretaceous } \\
87.4 \pm 2 \mathrm{~m} \cdot \mathrm{y} .\end{array}$ & $\begin{array}{l}\text { Fine- to medium-grained } \\
\text { granodiorite intrudes upper } \\
\text { Triassic clastic sedimentary } \\
\text { rocks. Bounded by fault along } \\
\text { southern margin. }\end{array}$ & $\begin{array}{l}\text { Speed and } \\
\text { Armstrong, 1971; } \\
\text { Spengler and } \\
\text { others, } 1979 ; \\
\text { Willden and } \\
\text { Speed, } 1974\end{array}$ \\
\hline $\mathrm{CH}-5$ & TJg & $\begin{array}{l}\text { Tertiary to } \\
\text { Jurassic, } \\
\text { Cretaceous (?) }\end{array}$ & $\begin{array}{l}\text { Granodiorite pluton intrudes } \\
\text { Triassic sedimentary rocks; } \\
\text { contact metamorphosed to } \\
\text { phyllite and slate. }\end{array}$ & $\begin{array}{l}\text { Spengler and } \\
\text { others, } 1979\end{array}$ \\
\hline $\mathrm{CH}-6$ & TJg & $\begin{array}{l}\text { Tertiary to } \\
\text { Jurassic, } \\
\text { Cretaceous (?) }\end{array}$ & $\begin{array}{l}\text { Older, massive quartz porphyry } \\
\text { and younger granodiorite } \\
\text { pluton; both intrude } \\
\text { Triassic(?) sedimentary rocks. }\end{array}$ & $\begin{array}{l}\text { Spengler and } \\
\text { others, } 1979 \\
\text { willden and } \\
\text { Speed, } 1974\end{array}$ \\
\hline $\mathrm{CH}-7$ & $\mathrm{Kg}$ & $\begin{array}{l}\text { Cretaceous } \\
79.6 \pm 2 \mathrm{~m} \cdot \mathrm{y}\end{array}$ & $\begin{array}{l}\text { Composite granite, grano- } \\
\text { diorite, and quartz } \\
\text { monzonite pluton cuts upper } \\
\text { Triassic to Middle Jurassic } \\
\text { volcanic siltstone, mudstone, } \\
\text { silty tuff, and limestone. } \\
\text { Contact rocks metamorphosed } \\
\text { to hornfels and schists. } \\
\text { Aplite, pegmatite, andesite, } \\
\text { and rhyolite dikes cut the } \\
\text { pluton and adjacent meta- } \\
\text { morphic rocks. Pluton to the } \\
\text { east (CH-lo) may be part of } \\
\text { this pluton (Willden and speed, } \\
\text { l974). }\end{array}$ & $\begin{array}{l}\text { Schilling, } 1965 \text {; } \\
\text { Spengler and } \\
\text { others, } 1979 \text {; } \\
\text { Willden and } \\
\text { Speed, } 1974\end{array}$ \\
\hline $\mathrm{CH}-8$ & TJg & $\begin{array}{l}\text { Tertiary to } \\
\text { Jurassic }\end{array}$ & $\begin{array}{l}\text { Quartz monzonite intrudes } \\
\text { Triassic or Jurassic meta- } \\
\text { volcanic rocks. Deeply } \\
\text { weathered and cut by aplite } \\
\text { and pegmatite dikes. }\end{array}$ & $\begin{array}{l}\text { Spengler and } \\
\text { others, } 1979 ; \\
\text { Willden and } \\
\text { Speed, } 1974\end{array}$ \\
\hline
\end{tabular}


$\mathrm{CH}-9$

$\mathrm{CH}-10$ $\mathrm{TJg}$

Tertiary to Jurassic, Cretaceous(?)

$\mathrm{CH}-\mathrm{II} \quad \mathrm{TJg}$

Tertiary to Jurassic, Cretaceous (?)
Granodiorite intrusive overlain by Tertiary volcanic rocks.

Complex of porphyritic quartz monzonite and granodiorite cut by abundant aplite dikes; intrudes strongly foliated and metamorphosed Triassic and Jurassic volcanic clastics and carbonates. Pluton may be part of pluton in sand springs Range (willden and speed, 1974).

Granodiorite and (or) quartz monzonite. Overlain by volcanic rocks.
Spengler and others, 1979; Tocher, 1956

Spengler and others, 1979; Willden and speeä, 1974

\section{CLARK COUNTY (CL)}

CL-1 Yg $\quad$ Precambrian Y
1,060 to

$1,450 \pm 25$
m.y.

$\mathrm{CL}-2$ $\mathrm{Ti}$

Tertiary

$\begin{array}{ll}\text { CL-3 Ti } & \text { Tertiary } \\ & 13.8 \pm 0.6 \\ & \mathrm{~m} \cdot \mathrm{y} \cdot\end{array}$

$\mathrm{Tg}$

Tertiary $12.5 \pm 0.5$ to $13.8 \pm 0.6 \mathrm{~m} \cdot \mathrm{y}$.

\section{$\mathrm{CL}-4$} Tg

Tertiary
$14.0 \pm 0.5$
m.y.
Tertiary
$26(+4,-2) \mathrm{m} \cdot \mathrm{y}$.

Precambrian $\mathrm{Y}$
Porphyritic granites and quartz monzonites intrude Precambrian gneisses, migmatites, older granites, pyroxenites, and hornblendites. Part of roof of a batholith with numerous cupolas, dikes, inclusions, and intrusion breccias.

Wilson Ridge pluton: Composed of dike-like masses in ranging composition from rhyolite to basalt and from porphyritic granite to porphyritic diorite.

Railroad Pass pluton: Granite porphyry, rhyolite, and trachyandesite. Overlain by alluvium and Tertiary volcanics.

Boulder City pluton: Granodiorite to granite pluton intrudes Tertiary Patsy Mine Volcanics. Highly faulted and brecciated.

Fine- to medium-grained quartz monzonite containing augite and biotite. Near Searchlight.

Knob Hill pluton: granite. Comprises most of area.

Gneiss, schist, and granite. Locally overlain by klippen of megabreccia composed of Precambrian granite, and rhyolitic and andesitic blocks. Area has undergone at least three major orogenic events subsequent to Paleozoic (Volborth, 1973).
Longwell and others, 1965 ; Spengler and others, 1979; Stewart, 1980; Volborth, 1962

Anderson, 1973; Spengler and others, 1979

Anderson and others, 1972 ; Armstrong, 1970b; Longwell and others, 1965 ; Schilling, 1965; spengler and others, 1979

Anderson and others, 1972:

Armstrong, $1970 \mathrm{~b}$;

Bingler and Bonham, 1973 ;

Callaghan, 1939;

Krueger and Schilling, 1971; Schilling, 1965; Spengler and others, 1979; Stewart, 1980; Volborth, 1973 


$\begin{array}{ll}\mathrm{CL}-5 \quad \mathrm{Yg} \quad & \text { Frecambrian } \mathrm{Y} \\ & 1,450 \pm 25 \\ & \mathrm{~m} \cdot \mathrm{Y} \cdot\end{array}$

CL-6 Kg cretaceous (?)

$\begin{array}{ll}\mathrm{CL}-7 \quad \mathrm{Tg} & \text { Tertiary } \\ & 8.1 \pm 2.7 \mathrm{to} \\ & 16.8 \pm 0.6 \mathrm{~m} \cdot \mathrm{Y} . \\ & \\ & \\ \mathrm{Yg} & \text { Precambrian } \mathrm{Y} \\ & 1,450 \pm 25 \mathrm{~m} \cdot \mathrm{Y} .\end{array}$

Gray, foliated gneissic granite intruded by pegmatitic dikes; contains subangular fragments of dark schist. Granite about 75 percent orthoclase crystals. Locally overlain by Tertiary rocks.

Quartz monzonite intrudes Precambrian $X$ medium- to fine-grained quartzfeldspathic gneiss. stock pervasively silicified and sericitizec. Bingler and Bonham (1973) mapped as Cretaceous, but schilling (1965) reported lead-alpha age of $927 \pm 90 \mathrm{~m} . \mathrm{y}$.

Spirit Mountain pluton: Microgranite, rapakivi granite, and muscovite granite cut by numerous rhyolite and diabase dikes.

Granite and metamorphic rocks surrounding Tertiary granite. Cut by numerous dikes of rhyolite, diabase, pegmatite and aplite. Westernmost outcrop lithologically similar to granite in area $\mathrm{CL}-5$.
Bingler and Bonhari, 1973; Hewett, I956; Longwell and others, 1965 ; spengler and others, 1979; stewart, 1980

Bingler and Bonham, 1973; Schilling, 1965 ; spengler and others, 1979

Anderson and others, 1972: Mathis, 1982 ; spengler and others, 1979; Stewart, 1980 ; Volborth, 1973

\section{DOUGLAS COUNTY (D)}

\begin{tabular}{|c|c|c|c|}
\hline \multirow[t]{4}{*}{$D-1$} & $\mathrm{Kg}$ & Cretaceous & $\begin{array}{l}\text { Non-porphyritic quartz } \\
\text { monzonite, granodiorite, and } \\
\text { hybrid mafic rocks. }\end{array}$ \\
\hline & KJC & $\begin{array}{l}\text { Cretaceous } \\
\text { and Jurassic }\end{array}$ & Diorite (?) \\
\hline & $\mathrm{Jg}$ & $\begin{array}{l}\text { Jurassic } \\
146 \pm 8 \mathrm{~m} \cdot \mathrm{y}\end{array}$ & $\begin{array}{l}\text { Porphyritic quartz monzonite, } \\
\text { hornblende-dacite porphyry, } \\
\text { and granite porphyry. }\end{array}$ \\
\hline & $\mathrm{N}: \mathrm{zg}$ & Mesozoic & $\begin{array}{l}\text { Medium- to coarse-grained } \\
\text { granodiorite, locally } \\
\text { Eoliated and lineated. Fine- } \\
\text { grained diorite locally. }\end{array}$ \\
\hline $\mathrm{D}-2$ & $\mathrm{Mzg}$ & Mesozoic & $\begin{array}{l}\text { Granciiorite, quartz monz- } \\
\text { quartz diorite. Plutons cut } \\
\text { Triassic and Jurassic meta- } \\
\text { sedimentary and metavolcanic } \\
\text { rocks. Cut by normal faults. }\end{array}$ \\
\hline
\end{tabular}

Bingler, 1977 ;

Hudson and

Oriel, I979;

Krueger and

Schilling, 1971;

spengler and

others, 1979

Spengler and stewart and others, 1982

\section{ELKO COUNTY (EL)}

EL-1 Kg cretaceous

EL-2 TJg Tertiary to
Jurassic

Quartz monzonite and granodiorite intrudes Permian sedimentary rocks. Cut by normal faults.

Granitic stock intrudes Permian sedimentary rocks. Cut by normal faults.
Spengler and others, 1979

spengler and others, 1979 
$\begin{aligned} \text { EL }-3 \text { TG } & \text { Tertiary } \\ & 36.4 \pm 1.5 \\ & \mathrm{~m} \cdot \mathrm{Y} .\end{aligned}$

$\begin{array}{ll}\text { EL-4 Tg } & \text { Tertiary } \\ & 12 \mathrm{~m} \cdot \mathrm{y} .\end{array}$

\begin{tabular}{|c|c|c|}
\hline EL-5 & $\mathrm{TJg}$ & $\begin{array}{l}\text { Tertiary } \\
\text { Jurassic }\end{array}$ \\
\hline & & $150 \mathrm{~m} \cdot \mathrm{y}$ \\
\hline$E L-6$ & $\mathrm{TJg}$ & $\begin{array}{l}\text { Tertiary } \\
\text { Jurassic }\end{array}$ \\
\hline
\end{tabular}

$\begin{array}{ll}\text { EL-7 Tg } & \text { Tertiary } \\ & 38 \cdot 3 \pm 1.3 \\ & \mathrm{~m} \cdot \mathrm{y} \cdot\end{array}$

TJg

Tertiary to

Jurassic

$E L-9$

TJg

$\mathrm{KJ} \mathrm{d}$

Tertiary to

Jurassic,

Tertiary (?)

Cretaceous

and Jurassic

EL-I0 Tg Tertiary
$33(+5,-2) \mathrm{m} \cdot \mathrm{y}$.

$E L-11$

$\mathrm{Tg}$

$\mathrm{Kg}$,

Jg

Cretaceous

and Jurassic

Tertiary

26 to $40 \mathrm{~m} \cdot \mathrm{y}$.

EL-12
Jgg,

Tertiary to

Jurassic and

Jurassic

EL-13 TJg
Mount Neva pluton:

Granodiorite stock intrudes

ordovician volcanic and

siliceous rocks. Partly

overlain by Tertiary tuffs.

lannie's Peak intrusive and Lone Mountain pluton: Quart: monzonite porphyry intrudes Devonian(?) Iimestone.

Granodiorite pluton intrudes Cambrian and ordovician sedimentary rocks. Partly overlain by rhyolite flows.

Granitic stocks; northern exposure intrudes Mississippian and Pennsylvanian sedimentary rocks. Southern exposure surrounded by alluvium.

Quartz monzonite and diorite stock intrude ordovician, Devoniar, and Silurian sedimentary rocks and Tertiary quartz porphyry. Numerous dikes of quartz-monzonite Forphyry and biotite-granodiorite porphyry. Date is on quartz monzonite.

Granodiorite and quartz porphyry stcck intrudes upper paleozoic sedimentary rocks.

Quartz monzonite(?) intrucies Permian and Lower Triassic sedimentary rocks.

Diorite intrudes Permian and Lower Triassic sedimentary rocks.

Quartz monzonite stock intrudes and metamorphoses paleozoic sedimentary rocks.

Harrison Pass pluton: Coarse-grained, porphyritic biotite granite; cuts sediments and quartzite of Devonian age.

Granite intrudes older Mesozoic sedimentary rock and pegmatitic granite mixture. Ruby Mountains described as part of metamorphic core complex (Snoke, 1980; Stewart, 1980)

Granodiorite and quartz monzonite intrude Permian sedimentary rocks.

Granodiorite(?) stock in area of Tertiary rhyolite flows.
Coats and McKee, 1972; McKee and Marvin, 1976; Spengler and others, 1979 Coats and Nickee, 1972 ; Lovejoy, 1959; spengler and others, 1979

Coats and others, 1965; Spengler and others, 1979

Spengler anc others, 1979

Evans and Ketner, 1971; Spengler and others, 1979

Ketner, 1973; Spengler and others, 1979

spengler and others, 1979

Schilling, 1965;

Smith and

Ketner, 1978;

spengler and others, 1979

Coats and others, 1965; Schilling, 1965;

Sharp, 1942;

Snoke, 1980;

spengler and others, 1979; Stewart, 1980 ; Willden and Kistler, 1969; willden and

others, 1967

spengler and others, 1979

Spengler and others, 1979 


\begin{tabular}{|c|c|c|c|}
\hline $\mathrm{EL}-14$ & TJg & $\begin{array}{l}\text { Tertiary to } \\
\text { Jurassic }\end{array}$ & Monzonite and syenite stocks. \\
\hline & $\mathrm{Kg}$ & $\begin{array}{l}\text { Cretaceous } \\
125(+19,-6) \mathrm{m} \cdot \mathrm{y} .\end{array}$ & $\begin{array}{l}\text { Monzonite and syenite stocks, } \\
\text { margins are finer grained and } \\
\text { more mafic. Intrudes permian } \\
\text { limestone and shale. }\end{array}$ \\
\hline$E L-15$ & TJg & $\begin{array}{l}\text { Tertiary to } \\
\text { Jurassic }\end{array}$ & $\begin{array}{l}\text { Discontinuous exposures of } \\
\text { granite, monzonite, and } \\
\text { granodiorite; intrude } \\
\text { Permian sedimentary rocks. }\end{array}$ \\
\hline EL-16 & TJg & $\begin{array}{l}\text { Tertiary to } \\
\text { Jurassic }\end{array}$ & $\begin{array}{l}\text { Quartz monzonite stock } \\
\text { intrudes Mississippian and } \\
\text { Pennsylvanian sedimentary } \\
\text { rocks overlain by } \\
\text { andesite flows. }\end{array}$ \\
\hline & $\mathrm{Jg}$ & $\begin{array}{l}\text { Jurassic } \\
140(+20,-7) \mathrm{m} . \mathrm{y} .\end{array}$ & $\begin{array}{l}\text { Quartz monzonite stock } \\
\text { intrudes Devonian } \\
\text { sedimentary rocks. }\end{array}$ \\
\hline $\mathrm{EL}-17$ & $\mathrm{Tg}$ & $\begin{array}{l}\text { Tertiary } \\
33.4 \pm 0.7 \mathrm{~m} . \mathrm{y} .\end{array}$ & $\begin{array}{l}\text { Locally coarse-grained } \\
\text { and porphyritic quartz } \\
\text { monzonite stock, intrudes } \\
\text { Cambrian limestone, and } \\
\text { is cut by aplitic and } \\
\text { mafic dikes. Uniform } \\
\text { texture. }\end{array}$ \\
\hline
\end{tabular}

Granger and others, 1957 ; Schilling, 1965; Spengler and others, 1979

Granger and others, 1957; spengler others, 1979

Schilling, 1965; Spengler and others, 1979

Granger and others, 1957; Hose and others, 1976 ; Mckee and Marvin, 1976; Schilling, 1965; spengler and others, 1979

\begin{tabular}{|c|c|c|c|c|}
\hline ES-1 & $\begin{array}{l}\text { Teg, } \\
\mathrm{Mzg}\end{array}$ & $\begin{array}{l}\text { Triassic (?) } \\
\text { and Mesozoic }\end{array}$ & $\begin{array}{l}\text { Granite and quartz monzonite } \\
\text { plutons intrude Middle } \\
\text { Triassic(?) Excelsior Formation } \\
\text { of greenstone, breccia, and } \\
\text { tuffaceous sandstone. over- } \\
\text { lain by Tertiary tuffs and } \\
\text { displaced by high-angle } \\
\text { normal faults. }\end{array}$ & $\begin{array}{l}\text { Spengler and } \\
\text { others, } 1979\end{array}$ \\
\hline $\mathrm{ES}-4$ & $\mathrm{Kg}$ & $\begin{array}{l}\text { Cretaceous } \\
63.7 \text { to } \\
71 \pm 1.4 \mathrm{~m} \cdot \mathrm{y} .\end{array}$ & $\begin{array}{l}\text { Lone Mountain pluton: } \\
\text { Coarse- to medium-grained } \\
\text { granite to quartz monzonite, } \\
\text { intrudes precambrian and } \\
\text { Cambrian sedimentary rocks. } \\
\text { Pluton roughly concordant } \\
\text { with and occupies core of } \\
\text { gently plunging anticline. } \\
\text { Cut by diabase dikes. }\end{array}$ & $\begin{array}{l}\text { Albers and } \\
\text { Stewart, 1972; } \\
\text { Bonham and } \\
\text { Garside, 1979; } \\
\text { Edwards and } \\
\text { McLaughlin, 1972; } \\
\text { Silberman and } \\
\text { others, 1975; } \\
\text { Spengler and } \\
\text { others, } 1979\end{array}$ \\
\hline
\end{tabular}


Mesozoic

$E S-5$

$\mathrm{Kg}$

Cretaceous

70.7 and

$74.5 \mathrm{~m} . \mathrm{y}$.

Cretaceous

80 to $90 \mathrm{~m} . \mathrm{y}$.

$\mathrm{Jg}$

Jurassic

$157 \mathrm{~m} \cdot \mathrm{y}$.

te $d$

Triassic

ES -6

Jg

Jurassic

$170 \mathrm{~m} \cdot \mathrm{y}$.
ES -7

$\mathrm{Tg}$

Tertiary

$42 \pm 2$ and

$5 \mathrm{I} \pm 2 \mathrm{~m} \cdot \mathrm{y}$.
Mesozoic
Aphanitic to medium-grained diorite to andesite.

Weepah pluton:

Quartz monzonite intrudes

Frecambrian and Cambrian sedimentary rocks. In southwestern part of area within Walker Lane fault zone.

other outcrops undescribed.

Quartz monzonite of Marble

Creek: Medium-grained, porphyritic quartz monzonite; in southern one-third of area.

Adamellite of Boundary Peak: Massive, medium-grained, leucocratic adamellite. Foliated near western contact; in northern twothirds of area.

Adamellite and granite of Pellisier Flats: Mediumto coarse-grained, locally porphyritic adamellite and granite, containing diorite inclusions; local leucocractic phase is cut by felsic and aplitic dikes. In white Mountains fault zone, on northwestern end of area, flaser and augen gneisses and mylonite formed by shearing. Anderson (1937) describes albitization of unit.

Hornblende diorite of Queen Canyon: Fine- to mediumgrained hornblende diorite. Cut by dikes of adamellite and granite of Pellisier Flats and dikes of hornblende granodiorite.

Adamellite of Beer Creek and Dyer pluton: Porphyritic, medium- to coarse-grained hornblende-biotite adamellite intrudes Lower Cambrian metamorphosed siltstone and quartzite.

Mineral Ridge pluton: Quartz monzonite and granitic pegmatite intrude Precambrian siltstone and limestone of Wyman Formation. Unit concordant with surrounding country rock, and occupies core of gently plunging anticline.

Rock compositionally similar to Mineral Ridge pluton.
Anderson, 1937; Crowder and others, 1972; Evernden and Kistler, 1970; Krauskopf, 1971; McKee, 1982; Mckee and others, 1982; Robinson and Crowder, 1973; Spengler and others, 1979

Krauskopf, 1971; Mckee and Nash, 1967; Robinson and Crowder, 1973; Robinson and others, 1976 ; Spengler and others, 1979; Stewart and others, 1974

Albers and Stewart, 1972; Spengler and others, 1979 


$\begin{array}{lll}\text { ES-8 } & \text { KJd, Jg, } & \text { Cretaceous to } \\ \text { Mzg } & \text { Jurassic, } \\ & \text { Jurassic, } \\ & \text { and Mesozoic }\end{array}$

ES-9 Mzg Mesozoic
Mesozoic

Cretaceous

Cretaceous and Jurassic

Jg Jurassic

$147.0+5$

to $17 \overline{0} \mathrm{~m} \cdot \mathrm{y}$.

$\begin{array}{cl}\text { ES-11 KJd } & \begin{array}{l}\text { Cretaceous } \\ \text { to Jurassic }\end{array} \\ & \text { Jg } \\ & 149 \pm 6 \text { to } \\ & 155 \pm 6 \mathrm{~m} \cdot \mathrm{y} .\end{array}$

Mzg Mesozoic

ES-12 Ti Tertiary
Quartz monzonite and diorite(?) plutons locally intrude Lower Cambrian and Ordovician sedimentary rocks. Locally overlain by Tertiary volcanic rocks. In walker Lane fault zone.

Clayton Ridge pluton: Quartz monzonite pluton intrudes Precambrian and Cambrian metamorphosed siltstone and quartzite, probably connected with Sylvania pluton (see ES-11) in subsurface. In southern half of area.

Northern outcrop is quartz monzonite pluton which intrudes precambrian and Cambrian siltstone, quartzite, and carbonates; in walker Lane fault zone.

Fine-grained leucocratic granite; southeasternmost tip composed of numerous dikes and masses that cut palmetto pluton.

Aphanitic to medium-grained diorite to andesite.

Palmetto pluton: Mediumto coarse-grained, locally porphyritic, locally melanocratic adamellite. Locally, small inclusions of diorite.

Aphanitic to medium-grained, dioritie to andesitie.

sylvania pluton:

Medium- to coarse-grained porphyritic adamelite; intrudes Precambrian Wyman Formation of siltstone and limestone. Partly overlain by Tertiary tuff. Concentric to and probably part of Silver Peak-PalmettoMontezuma orocline. Cut by high-angle normal faults.

Coarse-grained monzonite(?) to granodiorite(?).

Monzonite and diorite pluton probably intrudes sedimentary rocks of Cambrian, Ordovician, and Mississippian age. Partly overlain by Tertiary volcanics; cut by high-angle normal fault.
Spengler and others, 1979; stewart and Carlson, 1978

Albers and stewart, 1972; Spengler and others, 1979

Albers and Stewart, 1972; McKee and Nelson, 1967; spengler and others, 1979; stewart and others, 1974

Albers and Stewart, 1972; Evernden and Kistler, 1970; McKee, 1968a; McKee and Nelson, 1967; spengler and others, I 979

Spengler and others, 1979

$\begin{array}{cl}\text { EU-1 Tg } & \text { oligocene } \\ & \text { or Eocene } \\ & 37 \pm 0.8 \\ & \mathrm{~m} \cdot \mathrm{y} \cdot\end{array}$

Granodiorite, some epidote and sericite alteration.
Evans, $1974 \mathrm{a}$, $1974 \mathrm{~b}$; Roberts and others, 1967 ; Spengler and others, 1979 
Cretaceous $106 \pm 2 \mathrm{~m} . \mathrm{Y}$.

KJd

Cretaceous and Jurassic $121 \pm 5 \mathrm{~m} \cdot \mathrm{y}$.

$\begin{array}{lll}\text { EU-2 } & \text { TJg } & \begin{array}{l}\text { Tertiary to } \\ \text { Jurasic }\end{array} \\ \text { EU-3 } & \text { Jg } & \text { Jurassic } \\ & & \\ \text { EU-4 } & \mathrm{KJg} & \\ & & \begin{array}{l}\text { Cretaceous and } \\ \text { Jurasic } \\ \end{array} \\ & & \text { t25 to } 150 \mathrm{~m} \cdot \mathrm{Y} \cdot\end{array}$

urassic $150 \mathrm{~m} \cdot \mathrm{y}$.

EU-5

Jurassic $165(+25,-8)$ $\mathrm{m} \cdot \mathrm{Y}$.

EU-7 $\mathrm{Tg}$

Tertiary

EU-8 Ti

Tertiary
Granitic pluton intrudes Ordovician sedimentary rocks.

Granite stock intrudes Cambrian and Ordovician dolomite and quartzite. stock cuts Roberts Mountain thrust.

Granodiorite, granite, diorite, and some gabbro; intrude Ordovician chert and shale. Hydrothermally altered locally. Cuts Roberts Mountain thrust.

Quartz monzonite pluton intrudes older Mesozoic volcanic rocks. Partly overlain by Tertiary volcanic rocks.

Granodiorite and $f$ inegrained monzodiorite pluton intrudes Pennsylvanian or Permian sandstones and Permian(t)guartz-latite porphyry. Local chloritization.

Granodiorite and quartz monzonite and lesser amounts of diorite, tonalite, alaskite, quartz albitite, and adamelite; intrudes sedimentary rocks of Pennsylvanian or Permian age and some Jurassic or Cretaceous volcanic rocks. Plutons cut by numerous dikes and irregular bodies of altered dacite and rhyodacite porphyry. Pervasive deuteric alteration.

Mill Canyon stock: Quartz monzonite with granodiorite border; intrudes carbonate rocks and cuts Roberts Mountain thrust.

Porphyritic granodiorite stock exposed in Keystone window of Roberts Mountain thrust. Rocks in eastern exposure intrude ordovician sedimentary rocks in upper thrust plate of Roberts Mountain thrust.

Muscovite alaskite pluton intrudes Paleozoic shales and carbonates.

Granodiorite porphyry pluton intrudes Ordovician carbonate and quartzite.

Diorite to granite stock intrudes ordovician carbonate rocks.
Spengler and others, 1979

Muffler, 1964; Spengler and others, 1979

Gilluly and Masursky, 1965; Muffler, 1964; Schilling, 1965; Spengler and others, 1979; Stewart and Mckee, 1977; Stewart and others, 1975: Wells and others, 1971;

Silberman and McKee, 1971 ; Spengler and others, 1979; stewart and others, 1975

Merriam and Anderson, 1942; Schilling, 1965 . Spengler and others, 1979

Spengler and others, 1979

Spengler and others, 1979 


\begin{tabular}{|c|c|c|}
\hline $\mathrm{H}-\mathrm{I}$ & $\mathrm{Kd}$ & $\begin{array}{l}\text { Cretaceous } \\
92.4 \pm 1.3 \text { and } \\
93.7 \pm 1.3 \mathrm{~m} \cdot \mathrm{y} .\end{array}$ \\
\hline $\mathrm{H}-2$ & $\mathrm{Kg}$ & $\begin{array}{l}\text { Cretaceous } \\
90.6 \pm 3.2 \\
\text { to } 120 \pm 15 \mathrm{~m} \cdot \mathrm{y} \cdot\end{array}$ \\
\hline $\mathrm{H}-3$ & $\mathrm{Kg}$ & Cretaceous \\
\hline
\end{tabular}

$\mathrm{H}-4$

Cretaceous $96.2 \pm 3.5$

$\mathrm{m} \cdot \mathrm{y}$.

$\mathrm{Kg}$

Cretaceous $100 \mathrm{~m} \cdot \mathrm{y}$.

$\mathrm{Kg}$

$\mathrm{Jd}$

Jurassic $147 \mathrm{~m} \cdot \mathrm{y}$.

$\mathrm{H}-5$ $\mathrm{Kg}$

Cretaceous $97.8 \pm 3$ and $99.5 \pm 5 \mathrm{~m} \cdot \mathrm{y}$.

$\begin{array}{lll}\mathrm{H}-6 & \mathrm{Kg}, & \text { Cretaceous } \\ & \mathrm{Mzg} & \text { and Mesozoic }\end{array}$

$\mathrm{H}-7$

$\mathrm{Ti}$

Tertiary

Puebio Mountains pluton:

Quartz diorite intrudes

Permian-Triassic schist, hornfels, and marble. Pueblo Mountains are an uplifted block; pluton cut by highangle normal faults.

Bilk Creek Mountains pluton: Granodiorite partly overlain by Tertiary volcanics.

Granodiorite plutons locally intruded by alaskite and partially overlain by Tertiary volcanics. Larger pluton bounded and cut by high-angle normal faults along western edge.

Four plutons intrude Permian and older volcanics and Triassic-Jurassic limestone, phyllite, slate, and quartzite. Partially overlain by Tertiary volcanics.

Duffer Peak Granodiorite, massive.

Rattlesnake Spring Granodiorite, coarse-grained, massive; in northeast part of area.

New York Peak Quartz Monzonite, medium- to coarse-grained; border facies of Duffer Peak and Rattlesnake spring Granodiorites.

Theodore Quartz Diorite, mediumgrained, massive, weakly foliated.

Santa Rosa Peak pluton:

Granodiorite, intrudes

Triassic metamorphic rocks;

cut by high-angle normal

faults. The metamorphic

aureole is as much as one $\mathrm{mi}$ wide and contains schist and hornfels. Locally overlain by Tertiary volcanic rocks and cut by high-angle normal faults.

Granodiorite. Main mass intrudes metasediments, cut by high-angle normal faults, faulted against metavolcanics, and partially overlain by Tertiary volcanics.

Dacite porphyry and microdacite plugs and small stocks. Larger feldspar crystals in porphyry altered to clay. Unit intrudes Pansy Lee Conglomerate (Cenozoic) and is overlain by dacite flows.
Fiebelkorn and others, 1982; Harrold, 1972; Spengler and others, 1979

Greene, 1976; Spengler and others, 1979; willden, 1964

Spengler and others, 1979; willden, 1964

Harrold, 1972; Smith, 1973 ; Spengler and others, 1979
Silberman and McKee, 1971; spengler and others, 1979; willden, 1964
Spengler and others, 1979; stewart and Carlson, 1978; willden, 1964

Spengler and others, 1979; willden, 1963 


$\begin{array}{ll}\mathrm{H}-11 \mathrm{Kg} & \text { Cretaceous } \\ & 88.3 \pm 1.8 \text { to } \\ & 92.2 \pm 1.8 \\ & \mathrm{~m} \cdot \mathrm{Y} .\end{array}$

Cretaceous(?) $135 \pm 15 \mathrm{~m} \cdot \mathrm{y}$.

$\begin{array}{lll}\mathrm{H}-14 & \begin{array}{l}\text { KJd, } \\ \text { Mzg }\end{array} & \begin{array}{l}\text { Cretaceous and } \\ \text { Jurassic and } \\ \text { Mesozoic }\end{array} \\ \mathrm{H}-15 & \mathrm{KJd} & \begin{array}{l}\text { Cretaceous } \\ \text { and Jurassic }\end{array} \\ \mathrm{H}-16 & \mathrm{KJd} & \begin{array}{l}\text { Cretaceous } \\ \text { and Jurasic }\end{array}\end{array}$

Diorite intrusives; plagioclase altered to clay.

Granodiorite, partly chloritized; intrudes Happy Creek Volcanics (Permian or older).

Granodiorite, partially overlain by Tertiary sediments and volcanics; bounded by high-angle normal fault on southwest.

Granodiorite, intrudes Triassic-Jurassic phyllite, slate, and quartzite; partially overlain by Tertiary andesite and.basalt.

Granodiorite, intrudes phyllite, limestone lenses, and quartzitic sandstone of Singas Formation. Country rock metamorphosed to schist and hornfels. Large diabase dikes and some of andesite, dacite, and rhyolite cut pluton and Singas Formation.

Osgood Mountains stock: Granodiorite intruded and metamorphosed Cambrian Preble Formation to phyllite hornfels, schist, marble, and tactite. Stock well jointed and unaltered. Area complexly faulted by thrust and high-angle normal faults.

Donnelly Peak pluton: Granodiorite intrudes Triassic-Jurassic phyllite, slate and quartzite. Partly overlain by Tertiary volcanics; bounded by highangle normal fault on western edge.

Granodiorite, diorite, and syenite plutons; intrudes Permian or older Happy Creek volcanics. Partly overlain by Tertiary andesite and basalt.

Diorite and granodiorite intrude permian-Triassic and older volcanic and sedimentary rocks.

Diorite intrudes phyllite, slate, and quartzite of Triassic-Jurassic age.

Diorite, intrudes Triassic shale, sandstone, limestone, and quartzite.
Spengler and others, 1979; willden, 1964

Spengler and others, 1979; willden, 1964

Spengler and others, 1979 ; Willden, 1964

Hotz and Willden, 1961 , 2964; Silberman and McKee, 1971 ; spengler and others, 1979

Spengler and others, 1979; willden, 1964

Spengler and others, 1979; willden, 1964

Spengler and others, 1979; Willden, 1964

spengler and others, 1979

Ferguson and others, 1951; spengler and others, 1979 


\begin{tabular}{|c|c|c|}
\hline $\mathrm{H}-17$ & $\mathrm{Kg}$ & $\begin{array}{l}\text { Cretaceous } \\
99 \pm 5 \text { to } \\
101 \pm 3 \mathrm{~m} \cdot \mathrm{y} .\end{array}$ \\
\hline $\mathrm{H}-1.8$ & $\begin{array}{l}\mathrm{TJg}, \\
\mathrm{Kg}\end{array}$ & $\begin{array}{l}\text { Tertiary } \\
\text { to Jurassic } \\
\text { and Cretaceous } \\
104 \pm 2 \text { and } \\
105 \pm 0.5 \mathrm{~m} \cdot \mathrm{y} \text {. }\end{array}$ \\
\hline $\mathrm{H}-19$ & $\mathrm{Jg}$ & $\begin{array}{l}\text { Jurassic } \\
145 \pm 3 \text { to } \\
160 \pm 3 \mathrm{~m} \cdot \mathrm{y} .\end{array}$ \\
\hline
\end{tabular}

Granodiorite intrudes Paleozoic metasedimentary and sedimentary rocks. Locally altered by silica.

Granodiorite plutons, intrude Paleozoic metasedimentary and sedimentary rocks.

Granodiorite intrudes Paleozic metasedimentary and sedimentary rocks.
Erickson and Marsh, $1974 \mathrm{a}$, $1974 \mathrm{~b}$; Ferguson and others, 1952; spengler and others, 1979

Gilluly, 1967 ; Silberman and Mckee, 1971; Spengler and others, 1979

Ferguson and others, 1952; Silberman and Mckee, 1971; spengler and others, 1979

LANDER COUNTY (LA)

\begin{tabular}{|c|c|c|c|c|}
\hline LA -1 & $\begin{array}{l}\mathrm{Tg}, \\
\mathrm{TJ} g\end{array}$ & $\begin{array}{l}\text { Tertiary } \\
38.0 \text { to } \\
38.5 \pm 0.8 \mathrm{~m} \cdot \mathrm{y} \\
\text { Tertiary to } \\
\text { Jurassic }\end{array}$ & $\begin{array}{l}\text { Copper Canyon stock: } \\
\text { Granodiorite and quartz } \\
\text { monzonite intrude } \\
\text { Cambrian and Pennsylvanian- } \\
\text { Permian sedimentary } \\
\text { and volcanic rocks. }\end{array}$ & $\begin{array}{l}\text { Ferguson and } \\
\text { others, } 1952 ; \\
\text { Roberts, } 1951, \\
1964 ; \text { Silberman } \\
\text { and Mckee, } 1971 ; \\
\text { Spengler and } \\
\text { others, } 1979 ;\end{array}$ \\
\hline & $\mathrm{Kg}$ & $\begin{array}{l}\text { Cretaceous } \\
87.0 \pm 1 \text { and } \\
87.2 \mathrm{~m} \cdot \mathrm{y}\end{array}$ & $\begin{array}{l}\text { Trenton Canyon stock: } \\
\text { Granodiorite intrudes } \\
\text { Pennsylvanian-Permian } \\
\text { sedimentary rocks. } \\
\text { Feldspar moderately } \\
\text { sericitized and chloritized. }\end{array}$ & $\begin{array}{l}\text { Stewart and } \\
\text { others, } 1975, \\
1977 \text {; Theodore } \\
\text { and others, } \\
1973\end{array}$ \\
\hline LA- 2 & $\mathrm{Tg}$ & $\begin{array}{l}\text { Tertiary } \\
36.7 \pm 0.7 \text { to } \\
38.0 \pm 0.8 \mathrm{~m} \cdot \mathrm{y} .\end{array}$ & $\begin{array}{l}\text { Granite Mountain stock: } \\
\text { Granodiorite and minor } \\
\text { quartz monzonite; intrudes } \\
\text { Ordovician, Silurian, } \\
\text { Devonian, and Triassic } \\
\text { volcanic and sedimentary } \\
\text { rocks. Much of stock } \\
\text { hydrothermally altered } \\
\text { and well jointed locally. }\end{array}$ & $\begin{array}{l}\text { Gilluly and } \\
\text { Gates, 1965; } \\
\text { Silberman and } \\
\text { and Mckee, 1971; } \\
\text { Silberman and } \\
\text { others, 1969; } \\
\text { Spengler and } \\
\text { others, } 1979 ; \\
\text { Stewart and } \\
\text { others, } 1977 ; \\
\text { Wrucke, 1974 }\end{array}$ \\
\hline$L A-3$ & $\mathrm{Jg}$ & $\begin{array}{l}\text { Jurassic } \\
151 \text { and } \\
153 \pm 3 \mathrm{~m} \cdot \mathrm{y}\end{array}$ & $\begin{array}{l}\text { McCoy stock: } \\
\text { Granodiorite and quartz } \\
\text { monzonite and minor } \\
\text { granite, alaskite, and } \\
\text { diorite. Intrudes } \\
\text { Triassic sedimentary } \\
\text { rocks. Locally overlain } \\
\text { by Tertiary volcanic rocks. }\end{array}$ & $\begin{array}{l}\text { Miller and } \\
\text { Silberman, 1977; } \\
\text { Silberman and } \\
\text { Mckee, } 1971 ; \\
\text { Spengler and } \\
\text { others, } 1979 ; \\
\text { Stewart and } \\
\text { others, } 1977\end{array}$ \\
\hline $\mathrm{LA}-4$ & $\mathrm{Jg}$ & $\begin{array}{l}\text { Jurassic } \\
155 \pm 3 \mathrm{~m} \cdot \mathrm{y} .\end{array}$ & $\begin{array}{l}\text { Cain Creek stock: } \\
\text { Granodiorite overlain } \\
\text { by Quaternary alluvium and } \\
\text { Tertiary volcanics. }\end{array}$ & $\begin{array}{l}\text { Silberman and } \\
\text { Mckee, } 1971 ; \\
\text { Spengler and } \\
\text { others, } 1979 ; \\
\text { Stewart and } \\
\text { others, } 1977\end{array}$ \\
\hline
\end{tabular}


Cretaceous $67.9 \pm 2.7 \mathrm{~m} \cdot \mathrm{y}$.

Cretaceous $7 \mathrm{I} .4 \pm 3 \mathrm{~m} . \mathrm{Y}$.

\begin{tabular}{|c|c|c|}
\hline \multirow[t]{2}{*}{$L A-6$} & $\mathrm{Ti}$ & Oligocene \\
\hline & Jg & $\begin{array}{l}\text { Jurassic } \\
168 \mathrm{~m} \cdot \mathrm{y} .\end{array}$ \\
\hline \multirow[t]{3}{*}{ LA -7} & $\mathrm{Kg}$ & $\begin{array}{l}\text { Cretaceous } \\
\text { about } 75 \mathrm{~m} . \mathrm{y}\end{array}$ \\
\hline & $\mathrm{Jg}$ & $\begin{array}{l}\text { Jurassic } \\
160.2 \pm 5 \text { and } \\
160.7 \pm 5 \mathrm{~m} \cdot \mathrm{y}\end{array}$ \\
\hline & & $\begin{array}{l}\text { Jurassic } \\
157 \pm 6 \text { and } \\
168 \mathrm{~m} \cdot \mathrm{y} \text {. }\end{array}$ \\
\hline LA- 8 & TKJ i & $\begin{array}{l}\text { Tertiary, } \\
\text { Cretaceous, } \\
\text { or Jurassic }\end{array}$ \\
\hline
\end{tabular}

Granodiorite and quartz monzonite; intrudes Ordovician chert, quartzite, greenstone, and pillow lavas. Overlain by Tertiary volcanic rocks.

Iowa Creek stock:

Granite and quartz monzonite intrude ordovician rocks. Located in east part of area.

Ravenswood stock:

Granite and quartz monzonite intrude Cambrian quartzite and shale.

Vesicular biotite dacite.

Granite intrudes silurian to Devonian Iimestone and siltstone.

Birch Creek pluton:

Medium- to coarse-grained granite, strongly sheeted.

Linka mine stock:

Biotite-hornblende quartz monzonite. In southeast part of area.

Austin pluton:

Quartz monzonite and granodiorite and minor granitic rocks ranging from diorite to alaskite. Intrudes lower Paleozoic sedimentary and volcanic rocks. Locally highly altered and silicified.

Fine- to coarse-grained, locally brecciated hornblende diorite intrusive, pervasively altered.
Silberman and McKee, I97I; Spengler and others, 1979 ; Stewart and others, 1977

McKee, $1968 \mathrm{~b}$; Spengler and others, 1979; Stewart and McKee, I 977

Krueger and Schilling, 1971; McKee, I $968 \mathrm{c}$, $1976 \mathrm{~b}$; spengler and others, 1979 ; Stewart and McKee, I 968; stewart and others, 1977

McKee, $1976 \mathrm{~b}$

\section{LINCOLN COUNTY (LI)}

\begin{tabular}{|c|c|c|}
\hline$L I-I$ & $\mathrm{Tg}$ & Tertiary \\
\hline LI -2 & TJg & $\begin{array}{l}\text { Tertiary } \\
\text { to Jurass }\end{array}$ \\
\hline$L I-3$ & $\mathrm{Tg}$ & $\begin{array}{l}\text { Tertiary } \\
27.7 \pm 0.9 \\
m \cdot y \cdot\end{array}$ \\
\hline
\end{tabular}

Tertiary

Coarse-grained granite.

Silver King stock:

Altered granodiorite porphyry intrudes Pennsylvanian-Devonian sedimentary rocks.

Bristol Range pluton: Quartz monzonite intrudes Precambrian, Cambrian, and Devonian carbonate and quartzite.

Blind Mountain stock: Granite to quartz monzonite or granodiorite. Located west of Stampede Gap.

Tertiary
Coarse-grained granite at north end of area.
Tschanz and Pampeyan, 1970

Tschanz and Pampeyan, 1970

Armstrong, 1970a; spengler and others, I979; Tschanz and Pampeyan, I970 


$\begin{array}{lll}\text { LI }-4 \quad \text { TJg } & \text { Tertiary } \\ & \text { to Jurassic }\end{array}$

\begin{tabular}{|c|c|c|}
\hline$L I-5$ & TKg & $\begin{array}{l}\text { Tertiary and } \\
\text { Cretaceous(?) }\end{array}$ \\
\hline & $\mathrm{Kg}$ & $\begin{array}{l}\text { Cretaceous } \\
88.1 \pm 2.7 \text { to } \\
95.5 \pm 3.0 \mathrm{~m} . \mathrm{y} .\end{array}$ \\
\hline
\end{tabular}

LI-6 Tg Tertiary

Ti Tertiary

$\begin{array}{lll}\text { LI -7 } & \text { Tri } & \text { Tertiary } \\ \text { LI -8 } & \text { Xm } & \text { Precambrian } X\end{array}$

Worthington Peak pluton: Leucocratic, porphyritic granite, intrudes ordovician and Devonian carbonates rocks and quartzite. Western exposure more mafic.

Granite intrudes Precambrian quartzite and Cambrian shale.

Lincoln stock: Granite, intrudes Devonian, Mississippian, and Pennsylvanian carbonate rocks and quartzite. Tungsten in contact rocks around southern exposure.

Granodiorite and granite intrude Tertiary volcanic rocks at the east outcrop and Precambrian and Cambrian carbonate rocks, quartzites, and shales at the west. May be in ring fracture zone of Caliente volcanic center.

Fine- to medium-grained diorite plugs and stocks. Locally in Cedar Range, unit grades to quartz monzonite.

Altered granite porphyry, rhyolitic (?).

Amphibole gneiss and strongly metamorphosed granite and pegmatite. spengler and others, 1979; Tschanz and Pampeyan, 1970

Krueger and Schilling, 197I; spengler and others, 1979

Ekren and others, 1977 : Spengler and others, 1979

Ekren and others, 1977

Tschanz and Pampeyan, 1970

\section{LYON COUNTY (L)}

\begin{tabular}{|c|c|c|}
\hline$L-1$ & $\mathrm{Mzg}$ & Cretaceous(?) \\
\hline$L-2$ & $\mathrm{Mzg}$ & Cretaceous (?) \\
\hline$L-3$ & $\mathrm{Kg}$ & $\begin{array}{l}\text { Cretaceous } \\
87.0 \pm 2.7 \\
\text { and } 90.0 \pm 2.7 \\
\mathrm{~m} \cdot \mathrm{y} .\end{array}$ \\
\hline & $\mathrm{Jg}$ & $\begin{array}{l}\text { Jurassic } \\
140 \pm 4 \text { and } \\
154 \pm 5 \mathrm{~m} \cdot \mathrm{y} \text {. }\end{array}$ \\
\hline
\end{tabular}

Quartz monzonite and granodiorite intrude TriassicJurassic metasedimentary rocks. Partly overlain by Tertiary volcanic rocks.

Quartz monzonite and granodiorite intrude TriassicJurassic metavolcanic rocks. In Walker Lane fault zone.

Porphyritic quartz monzonite, quartz monzonite, and granodiorite plutons intrude Triassic-Jurassic metasedimentary and metavolcanic rocks. Locally hydrothermally altered.

Quartz monzonite and granodiorite intrude TriassicJurassic metavolcanic rocks; volcanic rocks; locally hydrothermally altered.

Quartz monzonite and granodiorite plutons intrude Triassic to Jurassic metavolcanic and metasedimentary rocks. Locally overlain by sedimentary rocks and alluvium. Hydrothermally altered and cut by high-angle normal faults.
Moore, 1969 . Spengler and others, 1979

Moore, 1969; Spengler and others, 1979

Bingler, 1978; Gilbert and Reynolds, 1973; Knopf, 1918 Krueger and Schilling, 1971; Moore, 1969; Spengler and others, 1979; stewart and others, 1981 


\begin{tabular}{|c|c|c|c|c|}
\hline$M-1$ & $\begin{array}{l}\mathrm{Kg}, \\
\mathrm{Mzg}\end{array}$ & $\begin{array}{l}\text { Cretaceous } \\
75 \text { and } 80 \pm 3.0 \\
\text { m.y. and } \\
\text { Mesozoic }\end{array}$ & $\begin{array}{l}\text { Medium- to coarse-grained } \\
\text { quartz monzonite, grano- } \\
\text { diorite, and granite plutons; } \\
\text { contain large, irregular- } \\
\text { shaped roof pendants of } \\
\text { Middle Triassic(?) } \\
\text { Excelsior Formation meta- } \\
\text { volcanic rocks. Locally } \\
\text { chloritized and sericitized. }\end{array}$ & $\begin{array}{l}\text { Bingler, 1978; } \\
\text { Evernden and } \\
\text { Kistler, 1970; } \\
\text { Gilbert and } \\
\text { Reynolds, 1973; } \\
\text { Spengler and } \\
\text { others, 1979; } \\
\text { Stewart and } \\
\text { Johannesen, } \\
\text { l981; }\end{array}$ \\
\hline & $\begin{array}{l}\mathrm{KJd} \text {, } \\
\mathrm{Jg}\end{array}$ & $\begin{array}{l}\text { Cretaceous } \\
\text { and Jurassic } \\
\text { and Jurassic } \\
139 \mathrm{~m} . \mathrm{Y}\end{array}$ & $\begin{array}{l}\text { Fine- to coarse-grained, } \\
\text { locally porphyritic, quartz } \\
\text { monzonite to granodiorite, } \\
\text { granodiorite, and quartz } \\
\text { diorite. Locally bleached, } \\
\text { hydrothermally altered, } \\
\text { and slightly foliated. }\end{array}$ & $\begin{array}{l}\text { Stewart and } \\
\text { others, } 198 \mathrm{i}\end{array}$ \\
\hline$M-2$ & $\begin{array}{l}\mathrm{TJg}, \\
\mathrm{Kg}, \\
\mathrm{Mzg}\end{array}$ & $\begin{array}{l}\text { Tertiary } \\
\text { to Jurassic, } \\
\text { Cretaceous, } \\
\text { and Mesozoic } \\
155 \pm 7 \text { and } \\
158 \pm 4 \mathrm{~m} \cdot \mathrm{y} \text {. }\end{array}$ & $\begin{array}{l}\text { Granitic plutons intrude } \\
\text { intermediate and felsic } \\
\text { volcanic rocks of Middle } \\
\text { Triassic(?) Excelsior } \\
\text { Formation. Sericitized, } \\
\text { saussuritized, and bleached } \\
\text { locally. }\end{array}$ & $\begin{array}{l}\text { Ekren and } \\
\text { Byers, 1978a, } \\
1978 \mathrm{c} \text {; Ross, } \\
1961 ; \\
\text { Spengler and } \\
\text { others, } 1979\end{array}$ \\
\hline$M-3$ & $\mathrm{Mzg}$ & Cretaceous(?) & $\begin{array}{l}\text { Granitic pluton intrudes meta- } \\
\text { sedimentary and sedimentary } \\
\text { rocks of Middle Triassic(?) } \\
\text { Excelsior Formation. }\end{array}$ & $\begin{array}{l}\text { Ross, } 1961 ; \\
\text { Spengler and } \\
\text { others, } 1979\end{array}$ \\
\hline \multirow[t]{2}{*}{$M-4$} & $\begin{array}{l}\mathrm{Kg}, \\
\mathrm{Mzg}\end{array}$ & $\begin{array}{l}\text { Cretaceous } \\
84.3 \text { to } \\
93.8 \mathrm{~m} \cdot \mathrm{y} \cdot \text { and } \\
\text { Mesozoic }\end{array}$ & $\begin{array}{l}\text { Quartz monzonite pluton } \\
\text { containing some granite and } \\
\text { granodiorite. Intrudes } \\
\text { Triassic sedimentary rocks } \\
\text { and Triassic(?) metavolcanic } \\
\text { rocks. Unit offset by strike- } \\
\text { slip faults of Walker Lane } \\
\text { fault zone in south part of } \\
\text { area. }\end{array}$ & $\begin{array}{l}\text { Ekren and } \\
\text { Byers, } 1978 \mathrm{~b}, \\
1978 \mathrm{~d} ; \\
\text { Evernden and } \\
\text { Kistler, } 1970 \\
\text { Ferguson and } \\
\text { Muller, } 1949 ; \\
\text { Spengler and } \\
\text { others, } 1979\end{array}$ \\
\hline & KJd & $\begin{array}{l}\text { Cretaceous } \\
\text { and Jurassic }\end{array}$ & $\begin{array}{l}\text { Diorite intruded by quartz } \\
\text { monzonite(?). }\end{array}$ & \\
\hline$M-5$ & $\begin{array}{l}\mathrm{Kg}, \\
\mathrm{Mzg}\end{array}$ & $\begin{array}{l}\text { Cretaceous(?) } \\
\text { and Mesozoic }\end{array}$ & $\begin{array}{l}\text { Quartz monzonite, albite } \\
\text { granite, granodiorite, and } \\
\text { some diorite plutons; lntrude } \\
\text { Triassic sedimentary rocks } \\
\text { and Jurassic sandstone and } \\
\text { volcanic rocks. Strike- } \\
\text { slip faults in walker Lane } \\
\text { fault zone border many } \\
\text { outcrops. }\end{array}$ & $\begin{array}{l}\text { Ekren and } \\
\text { Byers, } 1978 \mathrm{~b} ; \\
\text { Ross, } 1961 ; \\
\text { Spengler and } \\
\text { others, } 1979\end{array}$ \\
\hline$M-6$ & $\begin{array}{l}\mathrm{Tg}, \\
\mathrm{Mzg}\end{array}$ & $\begin{array}{l}\text { Tertiary } \\
40 \pm 10 \mathrm{~m} \cdot \mathrm{y} \\
\text { and Mesozoic }\end{array}$ & $\begin{array}{l}\text { Granodiorite and quartz } \\
\text { monzonite plutons intrude } \\
\text { Triassic Luning Formation. } \\
\text { Numerous felsic and mafic } \\
\text { dikes in and around margins. } \\
\text { Area tectonically active. }\end{array}$ & $\begin{array}{l}\text { Ferguson and } \\
\text { Muller, 1949; } \\
\text { Gianelia and } \\
\text { Callaghan, 1934; } \\
\text { Knopf, 1921; } \\
\text { Schiling, 1965; } \\
\text { Spengler and } \\
\text { others, } 1979\end{array}$ \\
\hline
\end{tabular}




\begin{tabular}{|c|c|c|c|c|}
\hline$M-7$ & $\begin{array}{l}\mathrm{Kg}, \\
\mathrm{Mzg}\end{array}$ & $\begin{array}{l}\text { Cretaceous } \\
75 \text { to } 94.5 \pm 2.5 \\
\mathrm{~m} \cdot \mathrm{y} \text {. and } \\
\text { Mesozoic }\end{array}$ & $\begin{array}{l}\text { Quartz monzonite, grano- } \\
\text { diorite, granite, and diorite } \\
\text { plutons probably intruded } \\
\text { along zones of weakness } \\
\text { associated with earlier } \\
\text { episodes of thrusting } \\
\text { (Ferguson and Muller, 1949); } \\
\text { hydrothermally altered and } \\
\text { faulted. Overlain by } \\
\text { Quaternary and Tertiary } \\
\text { volcanic rocks. }\end{array}$ & $\begin{array}{l}\text { Ekren and } \\
\text { Byers, 1978d; } \\
\text { Evernden and } \\
\text { Kistler, 1970; } \\
\text { Ferguson and } \\
\text { Muller, 1949; } \\
\text { Fergusson and } \\
\text { others, 1954; } \\
\text { Speed and } \\
\text { Kistler, 1980; } \\
\text { Spengler and } \\
\text { others, 1979; } \\
\text { Stewart and } \\
\text { Johannesen, } 1981\end{array}$ \\
\hline$M-8$ & $\begin{array}{l}\mathrm{Kg}, \\
\mathrm{Mzg}\end{array}$ & $\begin{array}{l}\text { Cretaceous } \\
68.7 \pm 1.8 \mathrm{~m} \cdot y . \\
\text { and Mesozoic }\end{array}$ & $\begin{array}{l}\text { Granodiorite and quartz } \\
\text { monzonite plutons intrude } \\
\text { Triassic sedimentary and } \\
\text { volcanic rocks. Pilot } \\
\text { Mountains bounded on east } \\
\text { and west sides by fault } \\
\text { scarps. }\end{array}$ & $\begin{array}{l}\text { Ferguson and } \\
\text { Muller, } 1949 ; \\
\text { Phoenix and } \\
\text { Cathcart, } 1952 ; \\
\text { Schilling, } 1965 ; \\
\text { Speed, } 1981 ; \\
\text { Spengler and } \\
\text { others, } 1979\end{array}$ \\
\hline$M-9$ & $\mathrm{Mzg}$ & Cretaceous (?) & $\begin{array}{l}\text { Granite pluton intrudes } \\
\text { Middle Triassic(?) } \\
\text { Excelsior Formation volcanic } \\
\text { rocks. Overlain by } \\
\text { Tertiary and Quaternary } \\
\text { volcanic rocks. }\end{array}$ & $\begin{array}{l}\text { Ross, } 1961 ; \\
\text { Spengler and } \\
\text { others, } 1979\end{array}$ \\
\hline$M-10$ & $\mathrm{Kg}$ & $\begin{array}{l}\text { Cretaceous } \\
86 \text { to } 101 \mathrm{~m} . \mathrm{y} \text {. }\end{array}$ & $\begin{array}{l}\text { Quartz monzonite and grano- } \\
\text { diorite pluton, locally } \\
\text { sericitized and chloritized. } \\
\text { Overlain by Tertiary and } \\
\text { Quaternary volcanic rocks. }\end{array}$ & $\begin{array}{l}\text { Evernden and } \\
\text { Kistler, 1970; } \\
\text { Ross, 1961; } \\
\text { Spengler and } \\
\text { others, } 1979 ; \\
\text { Stewart and } \\
\text { Johannesen, } 1981\end{array}$ \\
\hline & $\mathrm{KJd}$ & $\begin{array}{l}\text { Cretaceous } \\
\text { and Jurassic } \\
91.5 \pm 4.6 \\
\text { to } 101 \pm 4 \mathrm{~m} \cdot \mathrm{y} \text {. }\end{array}$ & $\begin{array}{l}\text { Diorite intrudes Excelsior } \\
\text { Formation. }\end{array}$ & \\
\hline
\end{tabular}

NYE COUNTY, NORTHERN HALF (NN)

$\begin{array}{ccc}\text { NN-1 Tg, } & \text { Tertiary } \\ & 53.9 \pm 1.5 \\ & \text { m. } . \text { and } \\ & \text { Tertiary to } \\ & \text { Jurassic }\end{array}$

Ophir and other plutons;

granodiorite and granite. In the north plutons intrude Cambrian quartzite, shale, and limestone which is locally metamorphosed to slate and marble. In the south plutons mostly intrude Lower Triassic volcanic rocks. Date is from Ophir pluton near Toiyabe Range Peak may not be actual crystallization age (speed and McKee, 1976).
Speed and McKee, 1976 ; Spengler and others, 1979; Stewart and McKee, 1977 
Clipper Gap pluton:

Locally porphyritic quartz monzonite and subordinate granodiorite and granite, cut by alaskite dikes. Intrudes Ordovician sedimentary and volcanic rocks.

Contact metamorphism and dikes of aplite and diorite border pluton which has two sets of joints. Locally overlain by Tertiary tuff and alluvium.

NN-3 TJg Tertiary to
Jurassic

\begin{tabular}{|c|c|c|}
\hline $\mathrm{NN}-4$ & $\begin{array}{l}\mathrm{Tg}, \\
\mathrm{TJg}, \\
\mathrm{KJd}\end{array}$ & $\begin{array}{l}\text { Tertiary, } \\
\text { Tertiary to } \\
\text { Jurassic, } \\
\text { and } \\
\text { Cretaceous } \\
\text { and Jurassic }\end{array}$ \\
\hline
\end{tabular}

$\begin{array}{ll}\text { NN-5 KJd } & \text { Cretaceous } \\ & \text { and Jurassic, } \\ \text { probably }\end{array}$
Cretaceous

\begin{tabular}{|c|c|c|}
\hline$N N-6$ & $\mathrm{Jg}$ & $\begin{array}{l}\text { Jurassic } \\
154 \pm 3 \\
\mathrm{~m} \cdot \mathrm{Y} \text {. }\end{array}$ \\
\hline $\mathrm{NN}-7$ & $\mathrm{Tg}$ & $\begin{array}{l}\text { Tertiary } \\
27(+4,-2) \\
31(+5,-2) \\
\text { m.y. }\end{array}$ \\
\hline
\end{tabular}

Granodiorite and some quartz monzonite intrude altered volcanic rocks of Middle Triassic(?) Excelsior Formation. Granodiorite is sericitized, saussuritized, and bleached. Cut by normal faults.

Lodi Hills and other plutons; Porphyritic, fine-grained granite, granodiorite, and minor diorite intrude Upper Triassic sedimentary rocks and metamorphosed Lower Triassic volcanic rocks. Cut by numerous granophyric dikes and sills. Lodi Hills pluton is easternmost pluton in area. Plutons locally overlain by Tertiary volcanic rocks.

Quartz diorite and lesser amounts of diorite and granodiorite. Intrudes Triassic volcanic and clastic volcanic and clastic rocks, and southern border is faulted against Triassic volcanic and sedimentary rocks.

Northumberland pluton: Medium-grained granodiorite stock intrudes ordovician sedimentary rocks.

Railroad and Silver Springs stocks: Quartz monzonite intrudes Cambrian shales and limestones which are locally metamorphosed. Large dikes radiate outward from stocks to the north and northeast. Along northwest and southern boundaries stocks may have intruded along thrust faults. Railroad stock, the larger stock, is highly fractured.
McKee, 1972, $1976 \mathrm{a}$;

Silberman and Mckee, 1971; Spengler and others, 1979; Stewart and MCKee, 1977

Ekren and Byers, 1978a; Spengler and others, 1979

Krueger and Schilling, 1971; Spengler and others, 1979; Vitaliano and Callaghan, 1963; Vitaliano and others, 1957

Silberling, 1959 ; spengler and others, 1979 ; Vitaliano, 1963

Silberman and Mckee, 1971; Spengler and others, 1979

Lumsden, 1964 ;

Moores and others, 1968 ; Schilling, 1965; spengler and others, 1979 
$\mathrm{NN}-8$ TJg

Tertiary

to Jurassic

$11.3 \pm 1.2 \mathrm{~m} . \mathrm{y}$.

NN -9

TJg

Tertiary

to Jurassic

NN-10

Tg

Tertiary

$29.4 \mathrm{~m} . \mathrm{y}$.

NN-11

$\mathrm{Kg}$

Cretaceous

$76.4 \pm 2.8$ and

$79.6 \pm 2.0 \mathrm{~m} . \mathrm{y}$.

Cretaceous

$\mathrm{NN}-12$

TJg

$\mathrm{KJd}$

NN-13 Kg

NN-14
Cretaceous

Tertiary to Jurassic

Cretaceous and Jurassic

Cretaceous

69 and

$77.4 \pm 2.3 \mathrm{~m} \cdot \mathrm{y}$.
Gabbs pluton:

Mostly granodiorite but on east flank of Paradise Range includes porphyritic granite; intrudes Triassic sedimentary rocks. Extensive hydrothermal alteration and silicification along margins of two westernmost exposures and along Paradise thrust fault. Numerous dikes and sills of granophyric composition. Date is from igneous body east of Gabbs and may be date of reheating by dikes and sills (Krueger and schilling, 1971).

Quartz monzonite porphyry intrudes Lower Jurassic sedimentary rocks. Locally overlain by Tertiary volcanic rocks.

Broad Creek pluton:

Quartz monzonite intrudes ordovician sedimentary rocks, Lower Triassic volcanic and sedimentary rocks, and middle Tertiary Darrough Felsite. Intrusive also included in Jett Canyon dike system. Eastern border faulted.

Belmont pluton:

Granite, granite porphyry, and porphyritic quartz monzonite intrude Cambrian and Ordovician sedimentary rocks.

Manhattan pluton:

Granitic pluton intrudes ordovician sedimentary rocks, generally massive. Locally overlain by alluvium. southernmost outcrop.

Granitic rock.

Diorite intrudes Upper Triassic Luning Formation of limestone, dolomite, conglomerate, and shale. Locally overlain by Tertiary volcanic rocks.

Troy Peak pluton:

Quartz monzonite and minor granodiorite intrude

Precambrian, Cambrian, and ordovician sedimentary rocks. Pluton dated at Tertiary age of $23(+4,-2)$ m.y., but field relationships suggest radiometric resetting.

Hall pluton:

Quartz monzonite porphyry intrudes Permian(?) tuffaceous sediments. stock is $2,400 \mathrm{ft}$ in diameter and mineralized with molybdenite.
Spengler and others, 1979

Krueger and Schilling, 1971; Spengler and others, 1979 ; Vitaliano, 1963 ; Vitaliano and Callahan, 1963; Vitaliano and others, 1957

Silberling, 1959; spengler and others, 1979 ;

Vitaliano, 1963

speed and McKee, 1976; Spengler and others, 1979

Ferguson, 1924;

Ferguson and Cathcart, 1954; Krueger and Schilling, 1971; spengler and others, 1979

Schilling, 1965;

Spengler and others, 1979

Bonham and Garside, 1979; Silberman and others, 1975; wright, 1976 


\begin{tabular}{|c|c|c|c|}
\hline $\mathrm{NN}-15$ & TJg & $\begin{array}{l}\text { Tertiary to } \\
\text { Jurassic } \\
59.3 \pm 7.4 \\
\text { and } 67.9 \pm 8.4 \\
\mathrm{~m} \cdot \mathrm{y} \text {. }\end{array}$ & $\begin{array}{l}\text { Fraziers Well and Black } \\
\text { Mountain plutons: } \\
\text { Quartz monzodiorite or } \\
\text { granodiorite intrudes } \\
\text { Ordovician sedimentary rocks; } \\
\text { locally metamorphosed to } \\
\text { phyllite, hornfels, and } \\
\text { marble. Dikes of rhyolitic } \\
\text { to dioritic composition cut } \\
\text { pluton. Overlain by } \\
\text { Tertiary volcanic rocks. }\end{array}$ \\
\hline$N N-16$ & $\mathrm{TJg}$ & $\begin{array}{l}\text { Tertiary } \\
\text { to Jurassic }\end{array}$ & $\begin{array}{l}\text { Granodiorite pluton partly } \\
\text { overlain by Tertiary volcanic } \\
\text { rocks and bounded on east by } \\
\text { normal fault. }\end{array}$ \\
\hline
\end{tabular}

Bonham and Garside, 1979; Spengler and others, 1979

Spengler and others, 1979

NYE COUNTY, SOUTHERN HALF (SN)

\begin{tabular}{|c|c|c|c|c|}
\hline & $\mathrm{Xm}$ & Precambrian $\mathrm{X}$ & $\begin{array}{l}\text { Gneiss and schist intruded } \\
\text { by rhyolite porphyry aikes. } \\
\text { May be underlain by pluton. }\end{array}$ & \\
\hline $\mathrm{SN}-2$ & $\mathrm{Mzg}$ & Mesozoic & $\begin{array}{l}\text { Gold Reed pluton: } \\
\text { Leucogranite intrudes and } \\
\text { metamorphoses Precambrian } \\
\text { Stirling Quartzite. } \\
\text { Partly covered by alluvium. }\end{array}$ & $\begin{array}{l}\text { Ekren and } \\
\text { others, } 1971 ; \\
\text { Spengler and } \\
\text { others, } 1979\end{array}$ \\
\hline $\mathrm{SN}-4$ & $\mathrm{Kg}$ & $\begin{array}{l}\text { Cretaceous } \\
91.8 \pm 2.8 \\
\mathrm{~m} \cdot \mathrm{y}\end{array}$ & $\begin{array}{l}\text { Climax stock: } \\
\text { Composite quartz monzonite } \\
\text { and granodiorite stocks } \\
\text { and granodiorite sills } \\
\text { intrude Ordovician } \\
\text { sediments. Pervasive } \\
\text { hydrothermal pyrite } \\
\text { mineralization, argilli- } \\
\text { zation, and (or) } \\
\text { chloritization of stock. } \\
\text { Gold Meadows stock: } \\
\text { Quartz monzonite intrudes } \\
\text { Cambrian and Precambrian } \\
\text { Wood Canyon Formation } \\
\text { clastics and stirling } \\
\text { Quartzite; sericitic } \\
\text { alteration along joints; } \\
\text { partially overlain by } \\
\text { Tertiary tuffs. West } \\
\text { outcrop. }\end{array}$ & $\begin{array}{l}\text { Barnes and } \\
\text { others, 1963; } \\
\text { Cornwall, } 1972 ; \\
\text { Gibbons and } \\
\text { others, 1963; } \\
\text { Houser and } \\
\text { Poole, 1960, } \\
\text { l961; } \\
\text { Marvin and } \\
\text { others, 1970; } \\
\text { Sargent and } \\
\text { Orkild, 1973; } \\
\text { Spengler and } \\
\text { others, } 1979\end{array}$ \\
\hline
\end{tabular}


Microgranite of Timber Mountain: Microgranite (granite prophyry of Carr and Quinlivan, 1966$)$; probably a hypabyssal ring dike that intrudes Timber Mountain Tuff.

$\mathrm{SN}-6$ $\mathrm{Tg}$

Miocene
Granite of Wahmonie Formation: Granodiôrite plugs intrude Miocene volcanic rocks.
Byers and others, 1976 ;

Carr and

Quinlivan, 1966 ;

spengler and

others, 1979

Ekren and

Sargent, 1965 ;

Spengler and

others, 1979

PERSHING COUNTY (P)

\begin{tabular}{|c|c|c|c|c|}
\hline$P-1$ & $\mathrm{Kg}$ & $\begin{array}{l}\text { Cretaceous } \\
92.0 \pm 3.9 \text { and } \\
95.2 \pm 6.3 \mathrm{~m} \cdot \mathrm{y}\end{array}$ & $\begin{array}{l}\text { Haystack Butte pluton: } \\
\text { Granodiorite intrudes } \\
\text { Triassic-Jurassic } \\
\text { sedimentary rocks. }\end{array}$ & $\begin{array}{l}\text { Johnson, } 1977 \\
\text { Smith and } \\
\text { others, } 1971 ; \\
\text { Spengler and } \\
\text { others, } 1979\end{array}$ \\
\hline & $\mathrm{Mzg}$ & Mesozoic & $\begin{array}{l}\text { Granodiorite intrudes } \\
\text { Triassic-Jurassic } \\
\text { sedimentary rocks. }\end{array}$ & \\
\hline $\mathrm{P}-2$ & $\mathrm{Kg}$ & $\begin{array}{l}\text { Cretaceous } \\
66 \cdot 5 \text { to } \\
90.0 \pm 2.7 \\
\mathrm{~m} \cdot y .\end{array}$ & $\begin{array}{l}\text { Grandiorite and quartz } \\
\text { monzonite plutons intrude } \\
\text { Triassic-Jurassic } \\
\text { sedimentary rocks. }\end{array}$ & $\begin{array}{l}\text { Krueger and } \\
\text { Schilling, } 1971 ; \\
\text { Silberling and } \\
\text { wallace, } 1967 ; \\
\text { Spengler and } \\
\text { others, } 1979 ; \\
\text { Tingley, } 1975\end{array}$ \\
\hline$P-3$ & $\mathrm{Mzg}$ & Cretaceous (?) & $\begin{array}{l}\text { Granite pluton intrudes } \\
\text { Triassic-Jurassic } \\
\text { sedimentary rocks. }\end{array}$ & $\begin{array}{l}\text { Ferguson and } \\
\text { others, } 1951 ; \\
\text { Spengler and } \\
\text { others, } 1979\end{array}$ \\
\hline \multirow[t]{2}{*}{$P-4$} & $\mathrm{Kg}$ & $\begin{array}{l}\text { Cretaceous } \\
91.3 \pm 3.8 \text { and } \\
93.9 \pm 6.0 \mathrm{~m} \cdot \mathrm{y}\end{array}$ & $\begin{array}{l}\text { Selenite Range pluton: } \\
\text { Granodiorite intrudes } \\
\text { Permian(?) volcanic and } \\
\text { sedimentary rocks, and } \\
\text { Triassic-Jurassic sedi- } \\
\text { mentary rocks. overlain by } \\
\text { Tertiary sedimentary rocks } \\
\text { and basalt flows; partly } \\
\text { bounded by high-angle } \\
\text { normal faults. }\end{array}$ & $\begin{array}{l}\text { Johnson, } 1977 \text {; } \\
\text { Smith and } \\
\text { others, } 1971 ; \\
\text { Spengler and } \\
\text { others, } 1979\end{array}$ \\
\hline & $\mathrm{Mzg}$ & Cretaceous (?) & $\begin{array}{l}\text { Heineke pluton: Lithology } \\
\text { and geologic setting similar } \\
\text { to selenite Range pluton. }\end{array}$ & \\
\hline$P-5$ & $\mathrm{Mzg}$ & Cretaceous (?) & $\begin{array}{l}\text { Seven Troughs pluton: } \\
\text { Granodiorite and some } \\
\text { leucogranite; intrudes } \\
\text { Triassic-Jurassic sedimentary } \\
\text { rocks. partly overlain by } \\
\text { Tertiary volcanic and } \\
\text { sedimentary rocks and cut } \\
\text { by high-angle normal faults. }\end{array}$ & $\begin{array}{l}\text { Johnson, } 1977 ; \\
\text { Spengler and } \\
\text { others, } 1979\end{array}$ \\
\hline$P-6$ & $\begin{array}{l}\mathrm{Kg}, \\
\mathrm{Mzg}\end{array}$ & $\begin{array}{l}\text { Cretaceous } \\
85.1 \pm 3.6 \\
\text { to } 103 \pm 4 \mathrm{~m} \cdot \mathrm{y} \\
\text { and Mesozoic }\end{array}$ & $\begin{array}{l}\text { Granodiorite plutons intrude } \\
\text { and have roof pendants of } \\
\text { Traissic-Jurassic sedimentary } \\
\text { rocks. Partly overlain by } \\
\text { Tertiary volcanic rocks. }\end{array}$ & $\begin{array}{l}\text { Johnson, } 1977 ; \\
\text { Smith and } \\
\text { others, } 1971 ; \\
\text { Spengler and } \\
\text { others, } 1979\end{array}$ \\
\hline
\end{tabular}


Tertiary to Jurassic $131 \pm 3$ and $149 \pm 3 \mathrm{~m} . \mathrm{y}$.

Triassic

$\begin{array}{ll}\text { P-9 TJg } & \begin{array}{l}\text { Tertiary to } \\ \text { Jurassic } \\ \text { Jg }\end{array} \\ \text { Jurassic }\end{array}$

\begin{tabular}{|c|c|c|}
\hline$P-10$ & $\mathrm{TJg}$ & $\begin{array}{l}\text { Tertiary to } \\
\text { Jurassic }\end{array}$ \\
\hline & $\mathrm{Jg}$ & $\begin{array}{l}\text { Jurassic } \\
153 \pm 3 \mathrm{~m} \cdot \mathrm{y}\end{array}$ \\
\hline $\mathrm{P}-11$ & $\mathrm{Kg}$ & $\begin{array}{l}\text { Cretaceous } \\
87.2 \pm 3.7 \\
\text { and } 90.2 \pm 6.1 \\
\mathrm{~m} . \mathrm{y} .\end{array}$ \\
\hline
\end{tabular}

P-12 TJg

Tertiary to Jurassic, possibly Cretaceous(?)

Kg

Cretaceous $69 \pm 3$ and $69.1 \pm 1.4 \mathrm{~m} \cdot \mathrm{y}$.

Rocky Canyon stock:

Granodiorite intrudes

Triassic volcanic and sedimentary rocks. Lamprophyre, diabase, and quartz diorite dikes and sills cut stock.

Intensely altered leucogranite plutons; intrude volcanic rocks of koppíato Group and Triassic sedimentary rocks.

Lee Peak pluton:

Quartz monzonite intrudes Paleozoic and Mesozoic sedimentary, metamorphic, and volcanic rocks.

Leucogranite pluton intrudes Pennsylvanian to Permian sedimentary and metamorphic rocks. Partly overlain by Tertiary volcanic rocks.

Clear Creek pluton: Granite

Grand Trunk Canyon pluton: Granite intrudes Pennsylvanian to Permian sedimentary and metamorphic rocks.

Granodiorite.

Tobin pluton:

Granite intrudes Pennsylvanian and Permian sedimentary and metamorphic rocks.

Nightingale-Shawave pluton: Granodiorite intrudes

Triassic-Jurassic sediments. pluton cut by mafic and felsite dikes and partly overlain by by Tertiary sedimentary and volcanic rocks.

Slightly micaceous granite pluton intruded by numerous granite porphyry and diorite porphyry dikes. Intrudes Upper Triassic sedimentary rocks.

New York Canyon stock: Quartz monzonite intrudes Triassic-Jurassic sedimentary rocks; cut by dikes and sills. North of Cornish Peak.

West Humboldt Range pluton: Granodiorite intrudes Triassic-Jurassic sedimentary rocks.

Humboldt lopolith:

Coarse-grained gabbro, moderately altered. Buena Vista Hills pluton: Highly scapolitized gabbro and leucogabbro.
Johnson, 1977;

Speed and

Armstrong, 1971;

Spengler and others, 1979; Tatlock and others, 1960; Wallace, silberling, and others, 1969; Wallace, Tatlock, and others, 1969

Ferguson and others, 1951; Johnson, 1977 : Silberman and McKee, 1971;

spengler and others, 1979

Johnson, 1977; spengler and others, 1979

Johnson, 1977; Silberman and McKee, 1971; spengler and others, 1979

Johnson, 1977; Smith and others, 1971; spengler and others, 1979; Tatlock, 1969

Johnson, 1977 ; Smith and others, 1971; speed, 1976 ; speed and Armstrong, 1971; speed and Jones, 1969 ; Spengler and others, 1969 ; wallace, Silberling, and others, 1969; willden and speed, 1974 
Stillwater pluton: Leucogranite intrudes Triassic volcanic rocks. High-angle normal fault on east margin.

P-13 Tg Tertiary

定g Triassic
Granite Mountain stock: Quartz monzonite intrudes older leucogranite, Pennsylvanian and Permian sedimentary rocks and greenstone, and Triassic volcanic and clastic rocks.

Granite Mountain pluton: Leucogranite intrudes Pennsylvanian and Permian sedimentary rocks and Triassic volcanic and sedimentary rocks. Partly overlain by Tertiary volcanic rocks.
Johnson, 1977 ; Spengler and others, 1979

STOREY COUNTY (S)

\begin{tabular}{|c|c|c|c|}
\hline$S-1$ & $\mathrm{Tg}$ & Tertiary & $\begin{array}{l}\text { Davidson granodiorite stock: } \\
\text { Weakly to moderately altered } \\
\text { granodiorite intrudes Tertiar } \\
\text { Alta Formation volcanics. } \\
\text { Closely associated with } \\
\text { Comstock Lode. }\end{array}$ \\
\hline & $\mathrm{Mzg}$ & Mesozoic & $\begin{array}{l}\text { Granodiorite plutons intrude } \\
\text { metasedimentary rocks. } \\
\text { Locally overlain by Tertiary } \\
\text { volcanic rocks. }\end{array}$ \\
\hline
\end{tabular}

WASHOE COUNTY (WS)

\begin{tabular}{|c|c|c|c|c|}
\hline WS-1 & $\mathrm{Kg}$ & $\begin{array}{l}\text { Cretaceous } \\
88.8 \pm 2.6 \\
\mathrm{~m} \cdot \mathrm{y}\end{array}$ & $\begin{array}{l}\text { Biotite-hornblende grano- } \\
\text { diorite batholith with } \\
\text { local phases of fine-grained } \\
\text { quartz diorite. In southern } \\
\text { part of area rock is foliated. } \\
\text { Western and eastern margins } \\
\text { bounded by high-angle normal } \\
\text { faults and central part cut } \\
\text { by normal faults. }\end{array}$ & $\begin{array}{l}\text { Bonham, } 1969 ; \\
\text { Krueger and } \\
\text { Schilling, } 19 \\
\text { Spengler and } \\
\text { others, } 1979\end{array}$ \\
\hline WS-2 & $\mathrm{Mzg}$ & Mesozoic & $\begin{array}{l}\text { Granodiorite plutons intrude } \\
\text { Triassic and Jurassic meta- } \\
\text { morphic rocks. plutons contain } \\
\text { large gabbro pendants. In } \\
\text { northern outcrops rocks } \\
\text { generally foliated and contains } \\
20 \text { percent mafic minerals; in } \\
\text { southern outcrops contains } \\
\text { less than } 10 \text { percent mafic } \\
\text { minerals. Plutons locally } \\
\text { overlain by volcanics. }\end{array}$ & $\begin{array}{l}\text { Bonham, } 1969 ; \\
\text { Spengler and } \\
\text { others, } 1979\end{array}$ \\
\hline WS -3 & $\mathrm{Mzg}$ & Mesozoic & $\begin{array}{l}\text { Granodiorite plutons partly } \\
\text { overlain by Tertiary volcanics. } \\
\text { In Walker Lane fault zone. }\end{array}$ & $\begin{array}{l}\text { Bonham, 1969; } \\
\text { Spengler and } \\
\text { others, } 1979\end{array}$ \\
\hline WS- 4 & $\mathrm{Mzg}$ & Mesozoic & $\begin{array}{l}\text { Granodiorite intrudes meta- } \\
\text { morphosed Triassic and } \\
\text { Jurassic sedimentary rocks. } \\
\text { Locally overlain by Tertiary }\end{array}$ & $\begin{array}{l}\text { Bonham, } 1969 \text {; } \\
\text { Spengler and } \\
\text { others, } 1979\end{array}$ \\
\hline
\end{tabular}




\begin{tabular}{|c|c|c|c|}
\hline WS -5 & Mzg & Mesozoic & $\begin{array}{l}\text { Granodiorite intrudes Mesozoic } \\
\text { hornfels and schists, and } \\
\text { locally overlain by Tertiary } \\
\text { volcanics and sedimentary } \\
\text { rocks. }\end{array}$ \\
\hline \multirow[t]{2}{*}{ WS -6} & $\mathrm{Tg}$ & $\begin{array}{l}\text { Pliocene or } \\
\text { Miocene }\end{array}$ & $\begin{array}{l}\text { Medium-grained quartz } \\
\text { monzonite grading to quartz } \\
\text { monzonite porphyry at } \\
\text { margins of stock; hydro- } \\
\text { thermally altered. }\end{array}$ \\
\hline & $\mathrm{Mzg}$ & Mesozoic & $\begin{array}{l}\text { Granodiorite intruded and } \\
\text { thermally metamorphosed volcanic } \\
\text { rocks; Pah Rah Range is in } \\
\text { Walker Lane fault zone. }\end{array}$ \\
\hline WS-7 & $\mathrm{Tg}$ & Tertiary & $\begin{array}{l}\text { Granodiorite porphyry intrudes } \\
\text { Tertiary tuff. Hydrothermal } \\
\text { alteration common. Plutons } \\
\text { align along strike-slip fault. }\end{array}$ \\
\hline \multirow[t]{2}{*}{ WS -8} & $\mathrm{Tg}$ & Tertiary & $\begin{array}{l}\text { Granodiorite cuts Tertiary } \\
\text { volcanics and older grano- } \\
\text { diorite. }\end{array}$ \\
\hline & $\mathrm{Mzg}$ & Mesozoic & $\begin{array}{l}\text { Granodiorite plutons intrude } \\
\text { Triassic and Jurassic meta- } \\
\text { volcanic and metasedimentary } \\
\text { rocks. Locally overlain by } \\
\text { Tertiary sedimentary and } \\
\text { volcanic rocks. }\end{array}$ \\
\hline WS-9 & $\mathrm{MzG}$ & Mesozoic & $\begin{array}{l}\text { Cranodiorite and quartz } \\
\text { monzonite batholith intrudes } \\
\text { Triassic(?) metasedimentary } \\
\text { and metavolcanic rocks. In- } \\
\text { trusive contacts are sharp. } \\
\text { Locally lineated and foliated. } \\
\text { Outcrops in northern part } \\
\text { extensively altered and } \\
\text { weathered. Locally over- } \\
\text { lain by Tertiary volcanic } \\
\text { rocks. Carson Range bounded } \\
\text { along east flank by recent } \\
\text { fault scarp more than } 40 \\
\text { ft high. }\end{array}$ \\
\hline
\end{tabular}

Bonham, 1969; Spengler and others, 1979

Bonham, 1969; Spengler and others, 1979

Bonham, 1969 ; Spengler and others, 1979

spengler and others, 1979

Bingler, 1977 ; spengler and others, 1979; Thompson, 1956; Thompson and White, 1964; white and others, 1964

WHITE PINE COUNTY (WP)

\begin{tabular}{|c|c|c|c|}
\hline WP-1 & $\mathrm{Tg}$ & Tertiary & $\begin{array}{l}\text { Quartz monzonite pluton } \\
\text { intrudes Permian carbonate } \\
\text { rocks. }\end{array}$ \\
\hline WP-2 & $\mathrm{Tg}$ & $\begin{array}{l}\text { Tertiary } \\
30 \pm 10 \text { and } \\
45 \pm 10 \mathrm{~m} \cdot \mathrm{y}\end{array}$ & $\begin{array}{l}\text { Quartz monzonite pluton } \\
\text { intrudes Pennsylvanian } \\
\text { limestone. }\end{array}$ \\
\hline$W P-3$ & $\mathrm{Tg}$ & Tertiary & $\begin{array}{l}\text { Granite and quartz monzonite } \\
\text { bodies intrude Cambrian to } \\
\text { Devonian sedimentary rocks; } \\
\text { southern outcrop is quartz } \\
\text { monzonite. }\end{array}$ \\
\hline$W P-4$ & $\mathrm{Tg}$ & $\begin{array}{l}\text { Tertiary } \\
32 \cdot 1 \pm 0.6 \text { and } \\
40.3 \pm 4 \mathrm{~m} \cdot \mathrm{y}\end{array}$ & $\begin{array}{l}\text { Quartz monzonite pluton } \\
\text { intrudes Precambriar. } \\
\text { metaseaimentary rocks and } \\
\text { Cambrian to Mississippian } \\
\text { sedimentary rocks. East } \\
\text { side bounded by normal fault }\end{array}$ \\
\hline
\end{tabular}

Spengler and others, 1979

Hose and others, 1976 ; Roberts and others, 1967; Spengler and others, 1979

Rigby, 1960; Spengler and others, 1979

Hose and others, 1976; Spengler and others, 1979 
Quartz monzonite pluton intrudes ordovician through Permian sedimentary rocks.

WP-6 Tg Tertiary

WP-7 TKg

Tertiary and Cretaceous $23.3 \pm 0.6$ to $72 \pm 7 \mathrm{~m} \cdot \mathrm{y}$.

$\begin{array}{lll}\text { WP-8 Tg } & \text { Tertiary } \\ 36.2 \pm 0.7 \mathrm{~m} . \mathrm{y} .\end{array}$

$\begin{array}{ll}\text { WP-9 Tg } & \text { Tertiary } \\ & 33.6 \pm 0.7 \mathrm{~m} \cdot \mathrm{y} \cdot \\ & \\ \mathrm{Kg} & \text { Cretaceous } \\ & 109 \pm 1.5 \text { and } \\ & 115 \pm 3 \mathrm{~m} \cdot \mathrm{y} .\end{array}$

$\begin{array}{cl}\text { WP-10 TKg Tertiary and } \\ \text { Cretaceous } \\ & 25.5 \pm 1.3 \text { and } \\ & 31 \pm 1.7 \mathrm{~m} \cdot \mathrm{y} .\end{array}$

WP-II Tg Tertiary

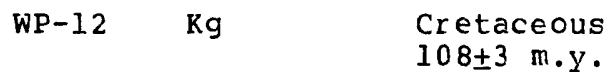

$\begin{aligned} \text { WP-13 } \mathrm{kg} & \text { Cretaceous } \\ & 90.4 \pm 2 \mathrm{~m} \cdot \mathrm{y} .\end{aligned}$

WP-14 Tg Tertiary

WP-15 Tg Tertiary $35.1 \pm 1.3 \mathrm{~m} \cdot \mathrm{y}$.
Quartz monzonite pluton intrudes Ordovician through Permian seảimentary rocks.

Mainly granodiorite but some quartz monzonite and granite. Intrudes middle Paleozoic sedimentary rocks. cut by north-south fractures.

Granite porphyry anà quartz monzonite pluton intrudes Precambrian metasedimentary and Cambrian to Permian sedimentary rocks. Normal fault along east side of largest outcrop.

Quartz monzonite pluton intrudes Precambrian metasedimentary rocks. East margin is normal fault.

Monzonite porphyry and quartz monzonite porphyry pluton intrudes Devonian to Permian sedimentary rocks. Partly overlain by Tertiary volcanic rocks.

Quartz monzonite and granodiorite intrude Paleozoic sedimentary rocks. Locally, pluton metamorphosed to gneiss. May be part of metamorphic corey (stewart, 1980).

Quartz monzonite pluton intrudes Precambrian metasedimentary rocks. May be part of metamorphic core complex (stewart, 1980).

Granodiorite pluton intrudes Devonian and Mississippian sedimentary rocks.

Quartz nionzonite pluton intrudes Cambrian limestone and shale.

Quartz monzonite fluton surrounded by alluvium.

Quartz monzonite pluton intrudes Pennsylvanian and Permian sedimentary rocks.
Hose and

others, 1976 ;

Spengler and

others, 1979

Hose and others, 1976 ; Spengler and others, 1979

Hose anỏ others, 1976 ; Spengler and others, 1979; Steele, 1960

Armstrong, 1970a; Fritz, 1968; Hose and others, 1976 ; Spengler and others, 1979

Armstrong, 1970a; Brokaw, 1967; Fritz, 1968; Hose and others, 1976; Spengler and others, 1979

Hose, 1981; Lee and others, 1970; Spengler and others, 1979; stewart, 1980

Hose and others, 1976 ; Misch and Hazzard, 1962; spengler and others, 1979 ; stewart, 1980

Hose and others, 1976; Nolan and others, 1974; Spengler and others, 1979

Armstrong, $1970 \mathrm{~b}$; Hose ano others, 1976 ; Spengler and others, 1979

Brokaw and others, 1973; spengler and others, 1979

Mckee and Marvin, 1976; Spengler and others, 1979 
Permian sedimentary rocks.

WP-17 $\mathrm{Kg}$ Jg
Cretaceous

Jurassic 156 to $160 \mathrm{~m} . \mathrm{y}$.

\section{Granitic rock.}

Quartz monzonite and granodiorite intrude Precambrian metasedimentary and Cambrian sedimentary rocks. Many conflicting radiometric dates from 17 to $240 \mathrm{~m} . \mathrm{y}$. , but probably Jurassic in age. Area may be part of metamorphic core complex (stewart, 1980).
Hose and

others, 1976;

Lee and

others, 1970;

Misch and

Hazzard, 1962;

spengler and

others, 1979;

stewart, 1980 ;

whitebread,

1969,1982 
Albers, J. P., and Stewart, J. H., 1972, Geology and mineral deposits of Esmeralda County, Nevada: Nevada Bureau of Mines and Geology Bulletin 78, 80 p.

Anderson, G. H., 1937, Granitization, albitization, and related phenomena in the northern Inyo Range of California-Nevada: Geological Society of America Bulletin, v. 48, p. 1-74.

Anderson, R. E., 1973, Large-magnitude late Tertiary strike-slip faulting north of Lake Mead, Nevada: U.S. Geological Survey Professional Paper 794, $18 \mathrm{p}$.

Anderson, R. E., Longwell, C. R., Armstrong, R. L., and Marvin, R. F., 1972, Significance of $\mathrm{K}-\mathrm{Ar}$ ages of Tertiary rocks from the Lake Mead region, Nevada-Arizona: Geological Society of America Bulletin, v. 83, no. 2, p. 273-287.

Armstrong, R. L., 1970a, Geochronolgy of Tertiary igneous rocks, of the Basin and Range province, western Utah, eastern Nevada, and vicinity, USA: Geochimica et Cosmochimica Acta, v. 34, no. 2, p. 203-232.

1970b, K-Ar dating using neutron activation for Ar analysis--comparison with isotope dilation Ar analyses: Geochimica et Cosmochimica Acta, v. 34, no. 2, p. 233-236.

Barnes, Harley, Houser, F. N., and Poole, F. G., 1963, Geologic map of the Oak Spring Quadrangle, Nye County, Nevada: U.S. Geological Survey Geologic Quadrangle Map GQ-214, scale $1: 24,000$.

Bedinger, M. S., Sargent, K. A., and Reed, J. E., 1984, Geologic and hydrologic characterization and evaluation of the Basin and Range province, relative to the disposal of high-level radioactive waste--Part I, Introduction and guidelines: U.S. Geological Survey Circular 904-A, $16 \mathrm{p}$.

Bingler, E. C., 1977, Geologic map of the New Empire Quadrangle, Nevada: Nevada Bureau of Mines and Geology Map 59, scale $1: 24,000$.

1978, Geologic map of the Schurz Quadrangle, Nevada: Nevada Bureau of Mines and Geology Map 60, scale 1:48,000.

Bingler, E. C., and Bonham, H. F., Jr., 1973, Reconnaissance geologic map of McCullough Range and adjacent areas, Clark County, Nevada: Nevada Bureau of Mines and Geology Map 45, scale $1: 125,000$.

Bonham, H. F., Jr.,1969, Geology and mineral deposits of Washoe and Storey Counties, Nevada, with a section on Industrial rock and mineral deposits, by $K$. G. Papke: Nevada Bureau of Mines and Geology Bulletin $70,140 \mathrm{p}$.

Bonham, H. F., Jr., and Garside, L. J., 1979, Geology of the Tonopah, Lone Mountain, Klondike, and northern Mud Lake Quadrangles, Nevada: Nevada Bureau of Mines and Geology Bulletin $92,142 \mathrm{p}$.

Brokaw, A. L., 1967, Geologic map and sections of the Ely Quadrangle, White Pine County, Nevada: U.S. Geological Survey Geologic Quadrangle Map GQ-697, scale 1:24,000.

Brokaw, A. L., Bauer, H. L., and Breitrick, R. A., 1973, Geologic map of the Ruth Quadrangle, White Pine County, Nevada: U.S. Geological Survey Geologic Quadrangle Map GQ-1085, scale $1: 24,000$. 
Byers, F. M., Jr., Carr, W. J., Christiansen, R. L., Lipman, P. W., Orkild, P. P., and Quinlivan, W. D., 1976, Geologic map of the Timber Mountain caldera area, Nye County, Nevada: U.S. Geological Survey Miscellaneous Investigations Series Map I-891, scale $1: 48,000$.

Callaghan, Eugene, 1939, Geology of the searchlight district, Clark County, Nevada: U.S. Geological Survey Bulletin 906-D, p. D135-D188.

Callaghan, Eugene, and Gianella, V. P., 1935, Earthquake of January 30 , 1934, at Excelsior Mountains, Nevada: Seismological Society of America Bulletin, v. 25, p. 161168.

Carr, W. J., and Quinlivan, W. D., 1966, Geologic map of the Timber Mountain Quadrangle, Nye County, Nevada: U.S. Geological Survey Geologic Quadrangle Map GQ-503, scale $1: 24,000$.

Christiansen, R. L., and Noble, D. C., 1965, Black Mountain volcanism of southern Nevada (abs.): Geological Society of America Special Paper 82, p. 246.

Coats, R. R., Marvin, R. F., and Stern, T. W., 1965, Reconnaissance of mineral ages of plutons in Elko County, Nevada, and vicinity, in Geological Survey Research 1965: U.S. Geological Survey Professional Paper 525-D, p. D11-D15.

Coats, R. R., and McKee, E. H., 1972, Ages of plutons and types of mineralization, northwestern Elko County, Nevada, in Geological Survey Research 1972: U.S. Geological Survey Professional Paper 800-C, p. C165-C168.

Cornwall, H. R., 1972, Geology and mineral deposits of southern Nye County, Nevada: Nevada Bureau of Mines and Geology Bulletin $77,49 \mathrm{p}$.

Crowder, D. F., Robinson, P. F., and Harris, D. L., 1972, Geologic map of the Benton Quadrangle, Mono county, California, and Esmeralda and Mineral Counties, Nevada: U.S. Geological Survey Geologic Quadrangle Map GQ-1013, scale $1: 62,500$.

Drewes, Harald, 1967, Geology of the Connors Pass Quadrangle, Schell Creek Range, east-central Nevada: U.S. Geological Survey Professional Paper 557, $93 \mathrm{p}$.

Edwards, George, and Mclauglin, W. A., 1972, Shell list no. 1, $\mathrm{K}-\mathrm{Ar}$ and $\mathrm{Rb}-\mathrm{Sr}$ age determinations of California, Nevada, and Utah rocks and minerals: Isochron/West, no. 3, p. 1-7.

Ekren, E. B., Anderson, R. E., Rogers, C. L., and Noble, D. C., 1971, Geology of northern Nellis Air Force Base Bombing and Gunnery Range, Nye County, Nevada: U.S. Geological Survey Professional Paper 651, 91 p.

Ekren, E. B., and Byers, F. M., Jr., 1978a, Preliminary geologic map of the Luning NE Quadrangle, Mineral and Nye Counties, Nevada: U.S. Geological Survey Open-File Report 78-915, scale $1: 48,000$.

1978b, Preliminary geologic map of the Luning SE Quadrangle, Mineral and Nye Counties, Nevada: U.S. Geological Survey Open-File Report 78-918, scale 1:24,000.

$1978 \mathrm{c}$, Preliminary geologic map of the Luning NW Quadrangle, Mineral County, Nevada: U.S. Geological Survey Open-File Report 78-916, scale 1:48,000. 
1978d, Preliminary geologic map of the Luning sw Quadrangle, Mineral County, Nevada: U.S. Geological Survey Open-File Report 78-917, scale 1:48,000.

Ekren, E. B., Orkild, P. P., Sargent, K. A., and Dixon, G. L., 1977, Geologic map of Tertiary rocks, Lincoln County, Nevada: U.S. Geological Survey Miscellaneous Investigations Series Map I-104l, scale 1:250,000.

Ekren, E. B., and Sargent, K. A., 1965, Geologic map of the Skull Mountain Quadrangle, Nye County, Nevada: U.S. Geological Survey Geologic Quadrangle Map GQ-387, scale 1:24,000.

Erickson, R. L., and Marsh, S. P., 1974a, Geologic map of the Iron Point Quadrangle, Humboldt County, Nevada: U.S. Geological Survey Geologic Quadrangle Map GQ-1175, scale $1: 24,000$.

$1974 \mathrm{~b}$, Geologic map of the Golconda Quadrangle, Humboldt County, Nevada: U.S. Geological Survey Geologic Quadrangle Map GQ-1174, scale $1: 24,000$.

Evans, J. G., 1974a, Geologic map of the Rodeo Creek NE Quadrangle, Eureka County, Nevada: U.S. Geological Survey Geologic Quadrangle Map GQ-1116, scale 1:24,000.

$1974 \mathrm{~b}$, Geologic map of the Welches Canyon Quadrangle, Eureka County, Nevada: U.S. Geological Survey Geologic Quadrangle Map GQ-1117, scale 1:24,000.

Evans, J. G., and Ketner, K. B., 1971, Geologic map of the Swales Mountain Quadrangle and part of the Adobe Summit Quadrangle, Elko County, Nevada: U.S. Geological Survey Miscellaneous Investigations Map I-667, scale l:24,000.

Evernden, J. F., and Kistler, R. W., 1970, Chronology of emplacement of Mesozoic batholith complexes in California and western Nevada: U.S. Geological Survey Professional Paper $623,42 \mathrm{p}$.

Ferguson, H. G., 1924, Geology and ore deposits of the Manhattan district, Nevada: U.S. Geological Survey Bulletin 723, 163 p.

Ferguson, H. G., and Cathcart, S. H., 1954, Geologic map of the Round Mountain Quadrangle, Nevada: U.S. Geological Survey Geologic Quadrangle Map GQ-40, scale 1:125,000.

Ferguson, H. G., and Muller, S. W. , 1949, Structural geology of the Hawthorne and Tonopah Quadrangles, Nevada: U.S. Geological Survey Professional Paper 216, 55 p.

Ferguson, H. G., Muller, S. W., and Cathcart, S. H., 1954, Geology of the Mina Quadrangle, Nevada: U.S. Geological Survey Geologic Quadrangle Map GQ-45, scale 1:125,000.

Ferguson, H. G., Muller, S. W., and Roberts, R. J., 1951, Geology of the Winnemucca Quadrangle, Nevada: U.S. Geological Survey Geologic Quadrangle Map GQ-11, scale 1:125,000, 2 sheets.

Ferguson, H. G., Roberts, R. J., and Muller, S. W., 1952, Geology of the Golconda Quadrangle, Nevada: U.S. Geological Survey Geologic Quadrangle Map GQ-15, scale 1:125,000.

Fiebelkorn, R. B., Walker, G. W., Macleod, N. S., Mckee, E. H., and Smith, J. G., 1982, Index to K-Ar age determinations for the State of Oregon: U.S. Geological Survey Open-File Report $82-596,40 \mathrm{p}$.

Fritz, W. H., 1968, Geologic map and sections of the southern Cherry Creek and northern Egan Ranges, White Pine County, Nevada: Nevada Bureau of Mines Map 35, scale 1:62,500. 
Garside, L. J., 1979, Geologic map of the Camp Douglas Quadrangle, Nevada: Nevada Bureau of Mines and Geology Map 63 , scale $1: 24,000$.

Gianella, V. P., and Callaghan, Eugene, 1934, Earthquake of December 20, 1932, at Cedar Mountain, Nevada, and its bearing on the genesis of Basin-Range structure: Journal of Geology, v. 42, p. 1-22.

Gibbons, A. B., Hinricks, E. N., Hansen, W. R., and Lemke, R. W., 1963, Geology of the Rainier Mesa Quadrangle, Nye County, Nevada: U.S. Geological Survey Geologic Quadrangle Map GQ-215, scale $1: 24,000$.

Gilbert, C. M., and Reynolds, M. W., 1973, Character and chronology of basin development, western margin of the Basin and Range province: Geological Society of America Bulletin, v. 84, no. 8, p. 2489-2510.

Gilluly, James, 1967, Geologic map of the Winnemucca Quadrangle, Pershing and Humboldt Counties, Nevada: U.S. Geological Survey Geologic Quadrangle Map GQ-656, scale 1:62,500.

Gilluly, James, and Gates, olcott, 1965, Tectonic and igneous geology of the northern Shoshone Range, Nevada, with a section on Gravity in Crescent Valley, by Donald Plouff, and Economic geology, by K. B. Ketner: U.S. Geological Survey Professional Paper $465,153 \mathrm{p}$.

Gilluly, James, and Masursky, Harold, 1965, Geology of the Cortez Quadrangle, Nevada, with a section on Gravity and aeromagnetic surveys, by D. R. Mabey: U.S. Geological Survey Bulletin 1175, $117 \mathrm{p}$.

Granger, A. E., Bell, M. M., Simmons, G. C., and Lee, Florence, 1957, Geology and mineral resources of Elko County, Nevada: Nevada Bureau of Mines Bulletin 54, 190 p.

Greene, R. C., 1976, Volcanic rocks of the McDermitt caldera, Nevada-Oregon: U.S. Geological Survey Open-File Report 76$753,80 \mathrm{p}$.

Harrold, J. L., 1972, K-Ar dates for plutonic rocks, Humboldt County, Nevada, and Harney County, Oregon: Isochron/West, no. 5, p. $1-5$.

Hewett, D. F., 1956, Geology and mineral resources of the Ivanpah Quadrangle, California and Nevada: U.S. Geological Survey Professional. Paper 275, 172 p.

Hose, R. K., 1981, Geologic map of the Mount Moriah further planning (RARE II) area, eastern Nevada: U.S. Geological Survey Miscellaneous Field Studies Map MF-1244-A, scale $1: 62,500$.

Hose, R. K., Blake, M. C., Jr., and Smith, R. M., 1976, Geology and mineral resources of White Pine County, Nevada: Nevada Bureau of Mines and Geology Bulletin 85, 105 p.

Hotz, P. E., and Willden, Ronald, 1961, Preliminary geologic map and sections of the osgood Mountains Quadrangle, Humboldt County, Nevada: U.S. Geological Survey Mineral Field Studies Map MF-16l, scale l:48,000.

1964, Geology and mineral deposits of the osgood Mountains Quadrangle, Humboldt County, Nevada: U.S. Geological Survey Professional Paper 431, $128 \mathrm{p}$. 
Houser, F. N., and Poole, F. G., 1960, Preliminary geologic map of the Climax stock and vicinity, Nye County, Nevada: U.S. Geological Survey Miscellaneous Geologic Investigations Map I-328, scale $1: 4,800,2$ sheets.

1961, Age relations of the Climax composite stock, Nevada Test Site, Nye County, Nevada, in Geological survey Research 1961: U.S. Geological Survey Professional Paper 424-B, p. B176-B177.

Hudson, D. M., and Oriel, W. M. , 1979, Geologic map of the Buckskin Range, Nevada: Nevada Bureau of Mines and Geology Map 64, scale 1:18,000.

Johnson, M. G., 1977, Geology and mineral deposits of Pershing County, Nevada: Nevada Bureau of Mines and Geology Bulletin $89,115 \mathrm{p}$.

Ketner, K. B., 1973, Preliminary map of the Hunter Quadrangle, Elko County, Nevada: U.S. Geological Survey Miscellaneous Field Investigations Map MF-539, scale $1: 24,000$.

Knopf, Adolph, 1918, Geology and ore deposits of the Yerington district, Nevada: U.S. Geological Survey Professional Paper $114,68 \mathrm{p}$.

1921, Ore deposits of Cedar Mountain, Mineral County, Nevada: U.S. Geological Survey Bulletin 725-H, p. 361-382.

Krauskopf, K. B., 1971, Geologic map of the Mt. Barcroft Quadrangle, California-Nevada: U.S. Geological Survey Geologic Quadrangle Map GQ-960, scale $1: 62,500$.

Krueger, H. W., and Schilling, J. H., 1971, Geochron/Nevada Bureau of Mines, K/Ar age determinations; List 1 : Isochron/West, no. I, p. 9-14.

Lee, D. E., Marvin, R. F., Stern, T. W., and Peterman, Z. E., 1970, Modification of potassium-argon ages by Tertiary thrusting in the snake Range, White Pine County, Nevada, in Geological Survey Research, 1970: U.S. Geological Survey Professional Paper 700-D, p. D92-D102.

Longwell, C. R., Pampeyan, E. H., Bowyer, Ben, and Roberts, R. J., 1965, Geology and mineral deposits of Clark County, Nevada: Nevada Bureau of Mines and Geology Bulletin 62, 218 p.

Lovejoy, D. W., 1959, Overthrust Ordovician and the Nannie's Peak intrusive, Lone Mountain, Elko County, Nevada: Geological Society of American Bulletin, v. 70, no. 5, p. 539-564.

Lumsden, W. W., Jr., 1964, Geology of the southern white Pine Range and northern Horse Range, Nye and white Pine Counties, Nevada: Los Angeles, University of California, Ph.D. dissertation, 249 p.

Marvin, R. F., Byers, F. M., Jr., Mehnert, H. H., Orkild, P. P., and Stern, T. W., 1970, Radiometric ages and stratigraphic sequence of volcanic and plutonic rocks, southern Nye and western Lincoln Counties, Nevada: Geological Society of America Bulletin, v.81, no. 9, p. 2657-2676.

Mathis, R. S., 1982, Mid-Tertiary detachment faulting in the southeastern Newberry Mountains, Clark County, Nevada, in Frost, E. G., and Martin, D. L., eds., Mesozoic-Cenozoic evolution of the Colorado River region, California, Arizona, and Nevada, Anderson-Hamilton volume: San Diego, California, Cordilleran Publishers, p. 326-340. 
McKee, E. H., 1968a, Geology of the Magruder Mountain area, Nevada-California: U.S. Geological Survey Bulletin 1251-H, $40 \mathrm{p}$.

1968b, Geologic map of the Ackerman Canyon Quadrangle, Lander and Eureka Counties, Nevada: U.S. Geological Survey Geologic Quadrangle Map GQ-761, scale 1:62,500.

1968c, Geologic map of the spencer Hot Springs Quadrangle, Lander County, Nevada: U.S. Geological Survey Geologic Quadrangle Map GQ-770, scale $1: 62,500$.

1972, Preliminary geologic map of the Wildcat Peak Quadrangle, and the western part of the Dianas Punch Bowl Quadrangle, Nevada: U.S. Geological Survey Miscellaneous Field Studies Map MF-337, scale $1: 62,500,2$ sheets.

1976a, Geology of the northern part of the Toquima Range, Lander, Eureka, and Nye Counties, Nevada: U.S. Geological Survey Professional Paper 931, $49 \mathrm{p}$.

$1976 \mathrm{~b}$, Geologic map of the Austin Quadrangle, Lander County, Nevada: U.S. Geological Survey Geologic Quadrangle Map GQ-1307, scale $1: 62,500$.

1982, Geologic map of the Sugarloaf roadiess area, Esmeralda County, Nevada: U.S. Geological Survey Miscellaneous Field Studies Map MF-1400-A, scale $1: 62,500$.

McKee, E. H., Diggles, M. F., Donahoe, J. L., and Elliot, G. S., 1982, Geologic map of the White Mountains wilderness and roadless areas, California and Nevada: U.S. Geological Survey Miscellaneous Field Studies Map MF-1361-A, scale $1: 62,500$.

Mckee, E. H., and Marvin, R. F., 1976, Summary of radiometric ages of Tertiary volcanic and selected plutonic rocks in Nevada, Part 5, northeastern Nevada: Isochron/West, no. 16 , p. $1-6$.

Mckee, E. H., and Nash, D. B., 1967, Potassium-argon ages of granitic rock in the Inyo batholith, east-central California: Geological Society of America Bulletin, v. 78, no. 5, p. 669-879.

McKee, E. H., and Nelson, C. A., 1967, Geologic map of the Soldier Pass Quadrangle, California and Nevada: U.S. Geological Survey Geologic Quadrangle Map GQ-654, scale $1: 62,500$.

Merriam, C. W., and Anderson, C. A., 1942, Reconnaissance survey of the Roberts Mountains, Nevada: Geological Society of America Bulletin, v. 53, no. 12, p. 1675-1727.

Miller, W. M., and Silberman, M. L., 1977, Cretaceous K-Ar age of hydrothermal alteration at the North Fish Creek porphyry copper prospect, Fish Creek Mountains, Lander County, Nevada: Isochron/West no. $18, \mathrm{p} .7$.

Misch, Peter, and Hazzard, J. C., 1962, Stratigraphy and metamorphism of late Precambrian rocks in central northeastern Nevada and adjacent Utah: American Association of Petroleum Geologists Bulletin, v. 46, no. 3, p. 289-343.

Moore, J. G., 1969, Geology and mineral deposits of Lyon, Douglas, and Ormsby Counties, Nevada, with a section on Industrial

minerals, by N. L. Archbold: Nevada Bureau of Mines and Geology Bulletin 75, 45 p. 
Moores, E. M., Scott, R. B., and Lumsden, W. W., 1968, Tertiary tectonics of the White Pine-Grant Range region, east-central Nevada, and some regional implications: Geological society of America Bulletin, v. 79, p. 1703-1726.

Muffler, L. J. P., 1964, Geology of the Frenchie Creek Quadrangle, north-central Nevada: U.S. Geological survey Bulletin 1179, $99 \mathrm{p}$.

Noble, D. C., Kistler, R. W., Christiansen, R. L., Lipman, P. W., and Poole, F. G., 1965, Close association in space and time of alkalic, calc-alkalic, and silicic volcanism in southern Nevada (abs.): Geological Society of America, Special Paper 82, Abstracts for 1964, p. 143-144.

Nolan, T. B., Merriam, C. W., and Blake, M. C., Jr., 1974, Geologic map of the Pinto summit Quadrangle, Eureka and White Pine Counties, Nevada: U.S. Geological Survey Miscellaneous Investigations Map I-793, scale 1:31:680, 2. sheets.

Phoenix, D. A., and Cathcart, J. B., 1952, Quicksilver deposits in the southern Pilot Mountains, Mineral County, Nevada: U.S. Geological Survey Bulletin 973-D, p. 143-171.

Rigby, J. K., 1960, Geology of the Buck Mountain-Rald Mountain area, southern Ruby Mountains, White Pine County, Nevada, in Boettcher, J. W., and Sloan, W. W., Jr., eds., Guidebook to the geology of east-central Nevada: Intermountain Association of Petroleum Geologists, llth Annual Field Conference, p. 173-180.

Roberts, R. J. 1951, Geologic map of the Antler Peak Quadrangle, Nevada: U.S. Geological Survey Geologic Quadrangle Map GQ-10, scale $1: 62,500$.

1964, Stratigraphy and structure of the Antler Peak Quadrangle, Humboldt and Lander Counties, Nevada: U.S. Geological Survey Professional Paper 459-A, p. Al-A93.

Roberts, R. J., Montgomery, K. M., and Lehner, R. E., 1967 , Geology and mineral resources of Eureka County, Nevada: Nevada Bureau of Mines Bulletin $64,152 \mathrm{p}$.

Robinson, P. T., and Crowder, D. F., 1973, Geologic map of the Davis Mountain Quadrangle, Esmeralda and Mineral Counties, Nevada, and Mono County, California: U.S. Geological Survey Geologic Quadrangle Map GQ-1078, scale 1:62,500.

Robinson, P. T., Stewart, J. H., Moiola, R. J., and Albers, J. P., 1976, Geologic map of the Rhyolite Ridge Quadrangle, Esmeralda County, Nevada: U.S. Geological Survey Geologic Quadrangle Map GQ-1325, scale $1: 62,500$.

Rose, R. L., 1969, Geology of parts of the Wadsworth and Churchill Butte Quadrangles, Nevada: Nevada Bureau of Mines Bulletin $71,27 \mathrm{p}$.

Ross, D. C., 1961, Geology and mineral deposits of Mineral County, Nevada: Nevada Bureau of Mines Bulletin 58, $98 \mathrm{p}$.

Sargent, K. A., and Bedinger, M. S., 1984, Geologic and hydrologic characterization and evaluation of the Basin and Range province relative to the disposal of high-level radioactive waste--Part II, Geologic and hydrologic characterization: U.S. Geological Survey Circular 904-B, [in press]. 
Sargent, K. A., and Orkild, P. P., 1973, Geologic map of the Wheelbarrow Peak-Rainier Mesa area, Nye County, Nevada: U.S. Geological Survey Miscellaneous Geologic Investigations Map I-754, scale $1: 48,000$.

Schilling, J. H., 1965, Isotopic age determinations of Nevada rocks: Nevada Bureau of Mines Report $10,79 \mathrm{p}$.

Sharp, R. P., 1942, Stratigraphy and structure of the southern Ruby Mountains, Nevada: Geological Society of America Bulletin, v. 53, p. 647-690.

Silberling, N. J., 1959, Pre-Tertiary stratigraphy and Upper Triassic paleontology of the Union district, Shoshone Mountains, Nevada: U.S. Geological Survey Professional Paper $322,67 \mathrm{p}$.

Silberling, N. J., and Wallace, R. E., 1967, Geologic map of the Imlay Quadrangle, Pershing County, Nevada: U.S. Geological Survey Geologic Quadrangle Map GQ-666, scale $1: 62,500$.

Silberman, M. L., Bonham, H. F., Jr., Garside, L. J., and Osborne, D. H., 1975, New K-Ar ages of volcanic and plutonic rocks and ore deposits in western Nevada: Isochron/West, no. 13, p. 13-21.

Silberman, M. L., and McKee, E. H., 1971, K-Ar ages of granitic plutons in north-certral Nevada: Isochron/West, no. 1 , $p$. 15-32.

Silberman, M. L., Wrucke, C. T., and Armbrustmacher, T. C., 1969, Age of mineralization and intrusive relations at Tenabo, northern Shoshone Range, Lander County, Nevada (abs.): Geological Society of America Abstracts with Programs, pt. 3, v. 1, p. 62 .

Smith, F. J., Jr., and Ketner, K. B., 1978, Geologic map of the Carlin-Pinon Range area, Elko and Eureka Counties, Nevada: U.S. Geological Survey Miscellaneous Investigations Series Map I-1028, scale $1: 62,500$.

Smith, J. G., 1973, Geologic map of the Duffer Peak Quadrangle, Humboldt County, Nevada: U.S. Geological Survey Miscellaneous Geologic Investigations Map I-606, scale $1: 48,000$.

Smith, J. G., McKee, E. H., Tatlock, D. B., and Marvin, R. E., 1971. Mesozoic granitic rocks in northwestern Nevada--a link between the Sierra Nevada and Idaho batholiths: Geological Society of America Bulletin, v. 82, p. 2933-2944.

Snoke, A. W., 1980, The transition from infrastructure to suprastructure $n$ the northern Ruby Mountains, Nevada, in Crittenden, M. D., Jr., Coney, J. P., and Davis, G. H., eds., Cordilleran metamorphic core complexes: Geological Society of America Memoir 153, p. 287-333.

Speed, R. C., 1976, Geologic map of the Humboldt lopolith and surrounding terrane, Nevada: Geological Society of America Map and Chart Series MC-14, scale $1: 63,500$.

1981, Preliminary geologic map of the Sodaville Quadrangle, Mineral County, Nevada: U.S. Geological Survey Miscellaneous Field Studies Map MF-1300, scale 1:24,000.

Speed, R. C., and Armstrong, R. L., 1971, Potassium-argon ages of some minerals from igneous rocks of western Nevada: Isochron/West, no. 1 , p. $1-8$. 
Speed, R. C., and Jones, T. A., 1969, Synorogenic quartz sandstone in the Jurassic mobile belt of western Nevada-Boyer Ranch Formation: Geological Society of America Bulletin, v. 80, no. 12, p. 2551-2584.

Speed, R. C., and Kistler, R. W., 1980, Cretaceous volcanism, Excelsior Mountains, Nevada: Geological Society of America Bulletin, v. 91, pt. 1, p. 392-398.

Speed, R. C., and McKee, E. H., 1976, Age and origin of the Darrough Felsite, southern Toiyabe Range, Nevada: U.S. Geological Survey Journal of Research, v. 4, no. 1, p. 75-81.

Spengler, R. W., Maldonado, Florian, Weir, J. E., Jr., Hanna, W. F., and Dixon, G. L., 1979, Inventory of granitic masses in the State of Nevada: U.S. Geological Survey Open-File Report $79-235,264 \mathrm{p}$.

Steele, Grant, 1960, Pennsylvanian-Permian stratigraphy of eastcentral Nevada and adjacent Utah, in Boettcher, J. W., and Sloan, W. W., Jr., eds., Guidebook to the geology of eastcentral Nevada: Intermountain Association of Petroleum Geologists 1lth Field Conference, p. 91-113.

Stewart, J. H., 1979, Geologic map of the Miller Mountain and Columbus Quadrangles, Mineral and Esmeralda Counties, Nevada: U.S. Geological Survey Open-File Report 79-1145, scale $1: 24,000$.

1980, Geology of Nevada--a discussion to accompany the geologic map of Nevada: Nevada Bureau of Mines and Geology Special Publication 4, 136 p.

Stewart, J. H., and Carlson, J. E., 1978, Geologic map of Nevada: Prepared by the U.S. Geological Survey in cooperation with the Nevada Bureau of Mines and Geology, scale 1:500,000.

Stewart, J. H., Carlson, J. E., and Johannesen, D. C., 1982, Geologic map of the Walker Lake $1^{\circ} x 2^{\circ}$ Quadrangle, California and Nevada: U.S. Geological Survey Miscellaneous Field Studies Map MF-1382-A, scale 1:250,000.

Stewart, J. H., and Johannesen, D. C., 1981, Geologic map of the Powell Mountain Quadrangle, Mineral County, Nevada, with Surficial geology, by J. C. Dohrenwend: U.S. Geological Survey Miscellaneous Field Studies Map MF-1268, scale $1: 62,500$.

Stewart, J. H., and McKee, E. H., 1968, Geologic map of the Mount Callaghan Quadrangle, Lander County, Nevada: U.S. Geological Survey Geologic Quadrangle Map GQ-730, scale 1:62,500. 1977, Geology and mineral deposits of Lander County, Nevada, Part I, Geology: Nevada Bureau of Mines and Geology Bulletin 88 , p. 1-59.

Stewart, J.H., Moore, W. J., and Zietz, Isidore, 1977, East-west patterns of Cenozoic igneous rocks, aeromagnetic anomalies, and mineral deposits, Nevada and Utah: Geological Society of America Bulletin, v. 88, no. 1, p. 67-77.

Stewart, J. H., Reynolds, M. W., and Johannesen, D. C., 1981, Geologic map of the Mount Grant Quadrangle, Lyon and Mineral Counties, Nevada, with Surficial geology, by J. C. Dohrenwend: U.S. Geological Survey Miscellaneous Field Studies Map MF-1278, scale $1: 62,500$. 
Stewart, J. H., Robinson, P. T., Albers, J. P., and Crowder, D. F. 1974, Geologic map of the Piper Peak Quadrangle, NevadaCalifornia: U.S. Geological Survey Geologic Quadrangle Map GQ-1186, scale $1: 62,500$.

Stewart, J. H., Walker, G. W., and Kleinhampl, F. J., 1975, Oregon-Nevada lineament: Geology, v. 3, p. 265-268.

Tatlock, D. B., 1969, Preliminary geologic map of Pershing County, Nevada: U.S. Geological survey open-file map, scale $1: 200,000$.

Tatlock, D. B., Wallace, R. E., and Silberling, N. J., 1960, Alkali metasomatism, Humboldt Range, Nevada (abs.): Geological Society of America Bulletin, v. 71, no. 12, pt. 2 , p. 2079-2080.

Theodore, T. G., Silberman, M. I., and Blake, D. W., 1973, Geochemistry and $\mathrm{K}-\mathrm{Ar}$ ages of plutonic rocks in the Battle Mountain mining district, Lander County, Nevada: U.S. Geological Survey Professional Paper 798-A, 24 p.

Thompson, G. A., 1956, Geology of the Virginia City Quadrangle, Nevada: U.S. Geological Survey Bulletin 1042-C, p. 45-77.

Thompson, G. A., and white, D. E., 1964, Regional geology of the Steamboat Springs area, Washoe County, Nevada: U.S. Geological Survey Professional Paper 458-A, p. Al-A52.

Tingley, J. V., 1975, K-Ar dates on granodiorite and related scheelite-bearing quartz veins at Tungsten, Pershing County, Nevada: Isochron/West, no. 12, p. 3-4.

Tocher, Don, 1956, Movement on the Rainbow Mountain fault (Nevada), in The Fallon-Stillwater earthquakes of July 6 , 1954, and August 23, 1954: Seismological Society of America Bulletin, v. 46, no. 1 , p. 10-14.

Tschanz, C. M., and Pampeyan, E. H., 1970, Geology and mineral deposits of Lincoln County, Nevada: Nevada Bureau of Mines Bulletin $73,187 \mathrm{p}$.

Vitaliano, C. J., 1963, Cenozoic geology and sections of the Ione Quadrangle, Nye County, Nevada: U.S. Geological Survey Mineral Investigations Field Studies Map MF-225, scale $1: 62,500$.

Vitaliano, C. J., Callaghan, Eugene, 1963, Geology of the Paradise Peak Quadrangle, Nevada: U.S. Geological Survey Geologic Quadrangle Map G!-250, scale $1: 62,500$.

Vitaliano, C. J., Callaghan, Eugene, and Silberling, N. L., 1957, Geology of Gabbs and vicinity, Nye County, Nevada: U.S. Geological Survey Mineral Investigations Field Studies Map MF-52, scale $1: 24,000$.

Volborth, Alexis, 1962, Rapakivi-type granites in the Precambrian complex of Gold Butte, Clark County, Nevada: Geological Society of America Bulletin, v. 73, p. 813-831.

1973, Geology of the granite complex of the Eldorado, Newberry, and northern Dead Mountains, Clark County, Nevada: Nevada Bureau of Mines and Geology Bulletin $80,40 \mathrm{p}$.

Wallace, R. E., Silberling, N. J., Irwin, W. P., and Tatlock, D. B., 1969, Geologic map of the Buffalo Mountain Quadrangle, Pershing County, Nevada: U.S. Geological Survey Geologic Quadrangle Map GQ-82l, scale $1: 62,500$. 
Wallace, R. E., Tatlock, D. B., Silberling, N. J., and Irwin, W. P., 1969, Geologic map of the Unionville Quadrangle, Pershing County, Nevada: U.S. Geological Survey Geologic Quadrangle Map GQ-820, scale $1: 62,500$.

Wells, J. D., Eliot, J. E., and Obradovich, J. D., 1971, Age of the igneous rocks associated with ore deposits, CortezBuckhorn area, Nevada, in Geological Survey Research, 1971: U.S. Geological Survey Professional Paper 750-C, p. Cl27C135.

White, D. E., Thompson, G. A., and Sandberg, C. H., 1964, Rocks, structure, and geologic history of Steamboat springs thermal area, Washoe County, Nevada: U.S. Geological survey Professional Paper 458-B, p. Bl-B63.

Whitebread, D. H., 1969, Geologic map of the wheeler Peak and Garrison Quadrangles, Nevada and Utah, : U.S. Geological Survey Miscellaneous Geologic Investigations Map I-578, scale $1: 48,000$.

1982, Geologic map of the Wheeler Peak and Highland Ridge further planning areas, White Pine County, Nevada: U.S. Geological Survey Miscellaneous Field Studies Map MF-1343-A, scale $1: 62,500$.

Willden, Ronald, 1963, General geology of the Jackson Mountains, Humboldt County, Nevada: U.S. Geological Survey Bulletin $1141-\mathrm{D}$, p. D1-D65.

1964, Geology and mineral deposits of Humboldt County, Nevada: Nevada Bureau of Mines and Geology Bulletin 59, 153 p.

Willden, Ronald, and Kistler, R. W., 1969, Geologic map of the Jiggs Quadrangle, Elko County, Nevada: U.S. Geological Survey Geologic Quadrangle Map GQ-859, scale $1: 62,500$.

Willden, Ronald, and Speed, R. C., 1974, Geology and mineral deposits of Churchill County, Nevada: Nevada Bureau of Mines and Geology Bulletin 83, $92 \mathrm{p}$.

Willden, Ronald, Thomas, H. H., and Stern, T. W., 1967, Oligocene or younger thrust faulting in the Ruby Mountains, northeastern Nevada: Geological Society of America Bulletin, v. 78, p. 1345-1358.

Wright, W. A., 1976, Molybdenite mineralization at the Hall property, Nye County, Nevada: Geological Society of America, Abstracts with Programs, v. 8, no. 6, p. 655-1198.

Wrucke, C. T., 1974, Geologic map of Gold Acres-Tenabo area, Shoshone Range, Lander County, Nevada: U.S. Geological Survey Miscellaneous Field Studies Map MF-647, scale $1: 15,840,2$ sheets. 